\title{
Komşuluk Birimi Ölçeğinde Yapılı Çevreyi Biçimlendiren Planlama Kararlarına İlişkin Sonuçların Ölçülmesine Yönelik Çok Değişkenli Bir Yöntem Önerisi
}

\section{Proposal of a Multivariate Method to Measure the Results of Planning Decisions Which Shape the Built Environment on the Neighborhood Unit Scale}

\author{
(1) Kadriye Burcu Yavuz Kumlu, ${ }^{1}$ (1) Şule Tüdeş, ${ }^{1}$ (i) Ruşen Keleş ${ }^{2}$ \\ ${ }^{1}$ Gazi Üniversitesi, Mimarlık Fakültesi, Şehir ve Bölge Planlama Bölümü, Ankara \\ ${ }^{2}$ Ankara Üniversitesi, Siyasal Bilgiler Fakültesi, Siyaset Bilimi ve Kamu Yönetimi Bölümü, Ankara
}

\section{ÖZ}

Kentler, günlük yaşantının temellerini oluşturan sosyoekonomik etkinliklerin süregeldiği yapı, çevre ve insandan oluşan sistemler bütünüdür. Kenti oluşturan sistemlerin bütünlüğünün sağlanması, günlük yaşamın devamlılığının da sağlanabilmesi için gerçekleştirilmesi gereken sosyoekonomik etkinliklerin sürekliliğinin sağlanması için önemlidir. Bu çerçevede, sözü geçen sosyoekonomik etkinlikler, kentlerin yapılı çevresi kapsamında gerçekleştirilir. Kent planlaması da kentin yapılı çevresini biçimlendiren en önemli araçlardandır. Planlama yoluyla mekâna ilişkin olarak alınan arazi kullanım, yoğunluk ve komşuluk birimi tasarımına ilişkin kararlar, içinde yaşadığımız yapılı çevreyi biçimlendiren kararlardır. Yaşadığımız yapılı çevre de insanların günlük yaşantısını doğrudan etkileyebilme kabiliyetine sahiptir. Bu etkinin derecesini tespit edebilmek amacıyla gerçekleştirilecek çalışmalarda yapılı çevrenin biçimlenmesinde rolü olan planlama kararlarına ilişkin sonuçların ölçülmesi gerekmektedir. Dolayısıyla bu çalışmayla; arazi kullanımı, yoğunluk ve komşuluk birimi tasarımına ilişkin planlama kararlarıyla biçimlenen yapılı çevrenin mevcut durumunun; sırasıyla kullanım çeşitliliği, yoğunluk durumu ve belirlenen

\begin{abstract}
Urban areas are considered as the integrated systems which are consisted of structures, environment and people, as well as they are holding the socio-economic activities that constitute the fundamentals of the everyday life. Providing the integration of the systems, which constitute the urban areas is significant in the sense that providing the maintenance of the daily life. In this context, the places, where aforesaid socioeconomic activities going on are the components of the built environment in the urban areas. Urban planning within this sense is conceived as the most important tool, which shape the components of the urban built environment. Land use, density and neighbourhood design decisions related with the urban space have a crucial role in structuring the built environment where we are living in and the built environment has the ability of directly affecting the daily life of its inhabitants. In order to determine these effects, it is required to measure the components, which shape the built environment. In this context, a method on the neighbourhood unit scale has been proposed to enable researchers to analyse numerically the built environment within the scope of land use diversity, density situation and
\end{abstract}

Bu makale; I. yazarın üzerinde çalışmakta olduğu ve 2. ve 3. yazarların tez danışmanlığını yaptığı doktora tez çalışmasının bir parçası olarak üretilmiştir.

Geliş tarihi: 25.10.2017 Kabul tarihi: 25.11.2018

Online yayımlanma tarihi: 21.12 .2018

İletişim: Kadriye Burcu Yavuz Kumlu.

e-posta: k.burcuyavuz@gmail.com
TMMOB

Şehir Plancıları Odası 
komşuluk birimi tasarım ölçütlerinin sağlanıp-sağlanmadığına yönelik sonuçlarının ele alınarak ölçülmesine ilişkin bir yöntem önerisi geliştirilmiştir. Geliştirilen yöntem, komşuluk birimi ölçeğindeki yapılı çevrenin arazi kullanımı, yoğunluk ve komşuluk birimi tasarımı çerçevesinde niceliksel bağlamda analizinin nasıl yapılabileceğine ilişkin varsayımsal (hypothetical) bir örnek üzerinde açıklanmıştır. Bu yöntem, esnek bir yapıya sahip olduğundan farklı komşuluk birimlerinde, farklı alt-ölçütler ele alınarak uygulanabilir. Böylelikle yapılı çevrenin arazi kullanımı, yoğunluk ve komşuluk birimi tasarımı doğrultusundaki mevcut durumu tespit edilerek, yapılı çevreyle kentlilerin ulaşım tercihleri, sağlık durumları (obezite, ruh sağlığı vb.), konut yer seçimi, toplumsallık bilinci ve aidiyeti gibi oldukça geniş bir yelpazede yer alan çeşitli olgular arasındaki ilişki belirlenebileceği gibi arazi kullanımı, yoğunluk ve komşuluk birimi tasarımı çerçevesinde yapılı çevrenin sosyal, çevresel ve ekonomik sürdürülebilirliğe etkisi de tespit edilebilir.

Anahtar sözcükler: Karma arazi kullanımı; komşuluk birimi tasarımı; planlama kararları; yapılı çevre; yoğunluk.

\section{Giriş}

Planlama, kenti oluşturan yapıyla ilişkili fiziksel sistemlerin, çevreyle ilişkili çevresel sistemlerin ve insanla ilişkili sosyoekonomik sistemlerin sürekliliğinin sağlanmasından sorumludur. Bu sürekliliğin sağlanması, günlük yaşantının kesintiye uğramadan devam ettirilmesi açısından oldukça önemlidir. Bu çerçevede Bourne (1976), mekânsal örüntünün, fiziksel ve sosyal bileşenleriyle bir bütün olarak en son alınan planlama kararları ve bu kararları etkileyen önceki planlama kararlarının meydana getirdiği sonuçlar bütünü biçiminde son halini aldığından bahseder. Dolayısıyla, kentsel yapı ve bu yapıyı biçimlendiren karar süreçlerinin mantıksal çerçevede birbirinden ayrılamayacağını söyler. Ancak bazı durumlarda, bu bileşenlerden birinin sürekliliği sağlanırken bir diğerinin sürekliliği tehlike altına girebilmektedir. Burada önemli olan, planlama yoluyla bu üç bileşen arasındaki dengenin sağlanması ve bütüncül bir sürekliliğe ulaşabilmektir.

Ekonomik yapının temel taşlarını oluşturan üretim ve tüketimin mekânı olan kentler, bu etkinlikleri gerçekleştiren bireylerin sosyal yapısının şekillendiği yerlerdir ve bir sosyal yapı çerçevesinde tanımlanan bireylerin üretim ve tüketime ilişkin kentte gerçekleştirdiği tüm etkinlikler sosyoekonomik etkinlikleri meydana getirmektedir. Bunlardan özellikle tüketime ilişkin olanlar yapılı çevreyle yakından ilişkilidir. Çünkü tüketici davranışları yapılı çevreyi biçimlendiren planlama kararları sonuçlarının niteliğine ve/veya niceliğine göre değişkenlik göstermektedir. Örneğin, tüketim çerçevesinde kentlerde gerçekleştirilen ve planlama kararlarının sonuçlarının nitelik ve/veya niceliğinden etkilenen en belirgin sosyoekonomik etkinliklerin başında alışveriş gelmektedir. Bir bölgede birbirini tamamlayan karma kullanımların yer alması, insanların alışveriş ve diğer sosyoekonomik etkinlikleri gerçekleştirebilmesi için buraya gelmesini teşvik edecektir. Diğer taraftan, belirli bir whether the certain neighbourhood design criteria are provided, which are the results of the planning decisions related with land use, density and neighbourhood design, respectively. This proposed method could be applied to different neighbourhoods, by considering various sub-criteria. Hereby, existing situation of the built environment, in the context of land use diversity, density and neighbourhood design could be analysed numerically. Therefore, it would be possible to determine whether there is a correlation among the obtained results with the travel behaviour, medical condition (as obesity, mental health etc.), household residential choice, sense of community and place attachment etc. of the inhabitants. As well, it would be possible to confirm if there is a relation between the results of the planning decisions in the sense of land use, density and neighbourhood design characteristics of the built environment with social, environmental and economical sustainability.

Keywords: Mixed land use; neighborhood unit design; planning decisions; built environment; density.

yapılaşma yoğunluğunun bulunduğu bir bölgede olası farklı kullanım biçimi sayısının çok sayıda ve yoğunluktan dolayı birbirine yakın olması, insanların bu bölgeye gelip alışveriş yapma, sosyalleşme ve farklı sosyal ve ekonomik etkileşimler içerisine girme isteğini artıracaktır. Benzer biçimde, yürüme mesafesi düşünülerek tasarlanmış bir komşuluk birimi, insanları mahallelerinde yürümeye teşvik ederek yerel alışveriş olanaklarının desteklenmesine öncülük edecektir. Ancak, özellikle yoğunluk kavramı için üzerinde durulması gereken önemli bir konu vardır: algı. Algılanan yoğunluk kişiden kişiye farklılık gösterebilir. Dolayısıyla yapılı çevreyi oluşturan bileşenlerin sosyoekonomik etkinlikleri nasıl şekillendirdiği konusundaki tahminler, kişilerin bu bileşenleri nasıl algıladıkları göz önünde bulundurularak yapılmalıdır.

Bu bilgilerin ışığında, planlama sürecini yalnızca arazi kullanımı, yoğunluk ve komşuluk birimi tasarımına ilişkin kararların alım süreci olarak nitelendirmek bu süreci tanımlamakta eksik kalacaktır. Buraya kadar açıklanan planlama kararları yapılı çevreye ilişkin, sonuçları yapılı çevreyi biçimlendiren kararlardır. Bunların yanı sıra kentlerdeki sosyoekonomik etkinliklerin çerçevesini biçimlendiren temel planlama kararlarından bahsetmek de mümkündür. Çünkü planlama, sadece yapılı çevrenin belirli ölçütler çerçevesinde biçimlendirilmesine yön veren bir disiplin değildir. Planlama aynı zamanda yerleşimlerle ilişkili sosyal, ekonomik ve çevresel koşulların uzun vadede belirli ölçütler çerçevesinde biçimlenmesinden de sorumludur. Örnek vermek gerekirse, sosyal koşulların biçimlendirilmesinde planlama sürecinde alınan nüfus ve istihdam kararlarının rolü büyüktür. Benzer biçimde, istihdam kararları ekonomik çerçeveyi belirleyen önemli bileşenlerden biridir. Yerleşimlere ilişkin çevresel çerçeveyse, planlama sürecinde alınan herhangi bir karar doğrultusunda biçimlenebilir. Örneğin arazi kulla- 
nım kararları doğal çevreyi oluşturan ögelerin korunmasında önemli bir role sahiptir. Diğer taraftan ilgili yazında çok sayıda araştırmacı yoğun, başka bir deyişle derişik kentlerin, çevresel sürdürülebilirliği desteklediği konusunda hemfikirdir.

Bu doğrultuda bu çalışmada yapılı çevre, insan eliyle biçimlenmiş kentsel fiziksel mekân olarak ele alınmıştır. Arazi kullanı- mına ilişkin planlama kararlarının bir sonucu olarak arazi kullanım çeşitliliği, yapılaşma ve nüfus yoğunluğuyla ilgili planlama kararlarının bir sonucu olarak yapılaşmanın yoğunluk durumu ve komşuluk birimi tasarımına ilişkin planlama kararlarının bir sonucu olarak bir komşuluk biriminin sahip olduğu özellikler; yapılı çevre örüntüsünün genel hatlarını oluşturmakta önemlidir. Tablo I'de ilgili yapılı çevreyi biçimlendiren planlama karar-

Tablo I. Farklı amaçlara sahip çalışmalarda yapılı çevreyi biçimlendiren planlama kararlarının sonuçlarının ölçülmesinde kullanılan yöntemler

\begin{tabular}{|c|c|c|c|}
\hline $\begin{array}{l}\text { Yapılı çevreyi biçimlendiren } \\
\text { planlama kararları }\end{array}$ & Araştırmacı & Çalışmanın amacı & $\begin{array}{l}\text { Yapılı çevreyi biçimlendiren } \\
\text { planlama kararlarının sonuçlarını } \\
\text { ölçmekte kullanılan yöntemler }\end{array}$ \\
\hline \multirow[t]{2}{*}{$\begin{array}{l}\text { Arazi kullanımına } \\
\text { ilişkin kararlar }\end{array}$} & Srinivasan (2002) & $\begin{array}{l}\text { Komşuluk birimi özellikleri } \\
\text { ile iş ve iş dışı amaçlı } \\
\text { yolculuklardaki ulaşım türü } \\
\text { seçimi arasındaki ilişkinin } \\
\text { tespit edilmesi }\end{array}$ & Dağıntı indeksi \\
\hline & Terzi ve Bölen (2010) & $\begin{array}{l}\text { İstanbul'daki konut alanlarının } \\
\text { mekânsal büyüme özelliklerinin } \\
\text { ortaya koyulması }\end{array}$ & $\begin{array}{l}\text { Saçaklanma indeksi (konut, ticaret ve } \\
\text { donatı kullanımlı binaların toplam } \\
\text { bina sayısına ayrı ayrı oranları } \\
\text { hesaplanmıştır. }\end{array}$ \\
\hline \multirow[t]{5}{*}{ Yoğunluğa ilişkin kararlar } & Holden ve Norland (2005) & $\begin{array}{l}\text { Arazi kullanım özellikleriyle } \\
\text { hane halklarının enerji ve ulaşım } \\
\text { tüketimleri arasındaki ilişkinin } \\
\text { tespit edilmesi }\end{array}$ & Birim alan başına düşen hane sayısı \\
\hline & Bölen vd. (2009) & $\begin{array}{l}\text { İstanbul'da yapılaşma yoğunluğu } \\
\text { ve yaşanabilir alan ilişkisinin } \\
\text { tespit edilmesi }\end{array}$ & $\begin{array}{l}\text { Taban alanı kat sayısı (TAKS) ve kat } \\
\text { alanı kat sayısı (KAKS) }\end{array}$ \\
\hline & Türkoğlu (1997) & $\begin{array}{l}\text { İstanbul'un planlı ve plansız } \\
\text { yapılaşmış konut alanlarında } \\
\text { yaşayanların memnuniyetinin } \\
\text { belirlenmesi }\end{array}$ & Hektar başına düşen kişi sayısı \\
\hline & Burton (2000) & $\begin{array}{l}\text { Yüksek yoğunluklu kent biçiminin } \\
\text { sosyal eşitliğin sürdürülmesindeki } \\
\text { rolünün incelenmesi }\end{array}$ & $\begin{array}{l}\text { Yapılı alan içerisinde bir hektara } \\
\text { düşen kişi ve hane halkı sayısı }\end{array}$ \\
\hline & & & Tasarımı biçimlendiren ölçütler \\
\hline \multirow[t]{2}{*}{$\begin{array}{l}\text { Komşuluk birimi } \\
\text { tasarımına ilişkin kararlar }\end{array}$} & Porta ve Renne (2005) & $\begin{array}{l}\text { Kentsel tasarım başlığı altında } \\
\text { komşuluk birimi ve sokağa özgü } \\
\text { bileşenlerin sürdürülebilirliği } \\
\text { nasıl etkilediğinin incelenmesi }\end{array}$ & $\begin{array}{l}\text { Erişilebilirlik, karma arazi kullanımı, } \\
\text { kamusal/özel alan, kendiliğinden } \\
\text { izlenirlik, sokakların birbiriyle } \\
\text { bağlantıları ve bina ve parsel sayıları }\end{array}$ \\
\hline & Yang (2008) & $\begin{array}{l}\text { Kentsel doku ile yaşam kalitesi } \\
\text { arasındaki ilişkinin belirlenmesi }\end{array}$ & $\begin{array}{l}\text { Yoğunluk, karma arazi kullanımı, } \\
\text { sokak bağlantısı ve konut çeşitliliği }\end{array}$ \\
\hline
\end{tabular}


ları ve bu kararların sonuçlarının çeşitli araştırmacılar tarafından hangi yöntemlerle ölçüldüğüne ilişkin, sonraki bölümlerde de üzerinde durulacak gerekli açıklamalar yer almaktadır.

Yapılı çevreyi biçimlendiren planlama kararlarının Tablo I'de tanımlanan sonuçları çerçevesinde ölçülmesiyle; yapılı çevre ile sürdürülebilirlik, ulaşım talebi, toplumsallık bilinci, aidiyet ve çevre vb. çok geniş bir yelpazede yer alan konu arasındaki ilişkinin incelenmesi mümkündür. Buraya kadar verilen bilgilerle ilişkili olarak, şunun da üzerinde durmak gerekir ki bu çalışmada, planlama sürecinde yapılı çevrenin biçimlenmesinde sadece doğrudan payı olan ve planlama süreci sonunda yapıIı çevrenin aslında bir bileşeni haline gelen planlama kararları (arazi kullanımı, yoğunluk ve komşuluk birimi tasarımına ilişkin planlama kararları) dikkate alınacak (bkz. Tablo 2) ve bu kararların sonuçlarının nasıl ölçülebileceği üzerine geliştirilen varsayımsal yöntem tanıtılacaktır.

Bu örneklerde görüldüğü üzere kullanım çeşitliliği, yoğunluk ve komşuluk birimi tasarımı çerçevesinde yapılı çevreyi biçimlendiren planlama kararlarına ilişkin sonuçlar, farklı araştırma- cılar tarafından farklı göstergeler ele alınarak ölçülmüştür (Lau vd., 2005; Dave, 20II). Çünkü bu göstergeler i) çalışmanın amacına, ii) çalışılan mekânsal ölçeğe (sayım bölgesi, mahalle, yapı adası, birim grid alan (ha, $\mathrm{km}^{2}, \ldots$ ), parsel vb.) ve iii) eldeki mevcut verinin özelliklerine göre değişkenlik göstermektedir. Özellikle mevcut verinin ölçeği, çalışmanın gerçekleştirileceği mekânsal ölçeğin ve kullanılacak göstergelerin belirlenmesinde temel yol göstericidir. Mevcut verinin ölçeğinin üst ölçek niteliğinde olması, alt ölçeklerde gerçekleştirilmesi gereken çalışmalarda (ör. bina ölçeği) anket veya saha çalışmaları gibi ilave veri toplama yöntemlerinin uygulanmasını gerektirebilmektedir. Örneğin, düşey düzlemdeki kullanım çeşitliliğinin ölçülmesi için bir binada yer alan farklı kullanım türlerinin biliniyor olması ve bu tip bir veriyi elde edebilmek için de araştırmacıların çoğu zaman saha araştırması yapması gerekmektedir.

Bunlara ek olarak yapılı çevreyi biçimlendiren planlama kararlarına ilişkin sonuçların ölçümü sonucu ortaya çıkan birimlerin farklı olması, üzerinde durulması gereken bir diğer konudur (ör. kullanım çeşitliliği 0-I arasında bir değer alırken, nüfus

Tablo 2. Yapılı çevreyi biçimlendiren planlama kararları ve bu kararların sonuçları

Yapılı çevreyi biçimlendiren $\quad$ Yapılı çevreyle ilişkilendirilebilecek planlama kararlarının sonuçları
planlama kararları

Arazi kullanımına ilişkin kararlar

Yoğunluğa ilişkin kararlar

Komşuluk birimi tasarımını biçimlendiren kararlar İdeal bir komşuluk birimini biçimlendiren tasarım ölçütleri (Farr, 2008'den yararlanılmıştır)

Tanımlı sınırlar

Yürünebilirlik

Karma kullanım \& konut türleri

Birbirine bağıı \& yürünebilir sokak örüntüsü

Farklı kentsel kullanımların varlığı
Karma arazi kullanımı

Tekil arazi kullanımı

Derişik yapılaşma

Az yoğun yapılaşma

Sınırların tanımlı olmaması

Tanımlı bir merkez ve sınırın varlı̆̆ı

Yürünebilir büyüklük

Yaya olarak erişilebilirliği düşük, yürünemeyen büyüklük

Çeşitli kullanımların (konut \& ticaret \& iş yeri vd.) bir arada bulunması ve farklı konut tipolojilerinin varlığı

Tek tür kullanım ve konut tipolojisi

Kısa yapı adalarının varlığı, yürünebilir nitelikteki sokak örüntüsünün oluşturulmasında olumlu bir katkı sağlamaktadır.

Uzun yapı adalarının varlığı, yürünebilir nitelikteki sokak örüntüsünün oluşturulmasına engeldir.

Yürünebilir sınırlar içerisinde farklı kentsel kullanımlar bulunmalıdır.

Farklı kentsel kullanımların yürünebilir sınırlar içerisinde bulunmaması, içerisinde yaşayanlar tarafından komşuluk birimi algısının zayıf veya olmaması anlamına gelebilmektedir. 
yoğunluğu kişi/ha cinsinden herhangi bir tam sayı değerini alabilir). Özellikle basit ağırlıklı toplam, analitik hiyerarşi süreci vb. gibi mekânsal çok ölçütlü karar verme analizlerinin uygulanacağı ve bu doğrultuda yapılı çevreyi oluşturan bileşenlerin, mekânsal indeksler geliştirilerek bütüncül bir yaklaşım içerisinde birlikte ölçülmesinin gerektiği araştırmalarda ölçüm sonucu ortaya çıkan farklı birimlerin aynı dili konuşuyor hale getirilmesi gerekmektedir. Dolayısıyla;

- Yapılı çevrenin sürdürülebilirlik, ulaşım, aidiyet, sağıık vb. üzerine etkilerinin incelenmesi için yapılı çevreyi biçimlendiren planlama kararlarına ilişkin sonuçların ölçülmesi gerekliliği,

- Bu ölçümlerin birlikte değerlendirilmesine olanak sağlayan bir mekânsal indeks yönteminin geliştirilmesi ihtiyacı ve

- Farklı amaç, ölçek ve göstergelere sahip çalışmalarda kullanılabilecek esnek bir model ihtiyacı

bu çalışmayı başlatan nedenler olarak sıralanabilir.

Buraya kadar açıklanan ve çeşitli araştırmacılar tarafından gerçekleştirilen ilgili yazın örnekleri (bkz. Tablo I), bu örneklere ilişkin kuramsal bilgiden çıkarılan sonuçlar ve çalışmayı başlatan nedenler göz önünde bulundurularak çalışmanın araştırma sorusu aşağıdaki gibi oluşturulmuştur:

Arazi kullanımı, yoğunluk ve komşuluk birimi tasarımı kararları çerçevesinde yapilı çevreyi biçimlendiren planlama kararlarına ilişkin sonuçlar (kullanım çeşitlilĭgi, derişiklik, tasarım ölçütlerinin sağlanıp-sağlanmadığı) nasıl ölçülebilir ve bu üç planlama kararı, meydana getirdikleri sonuçları çerçevesinde ölçüm sürecine bir arada nasıl dâhil edilebilir?

Oluşturulan bu araştırma sorusu, yapılı çevrenin biçimlenmesini anlamayı gerektiren araştırmalarda kullanılabilecek esnek bir yöntem önerisi geliştirilerek cevaplandırılmışır. Geliştirilen yöntemde, eş alanlar oluşturmaya imkân vererek mekânsal indeksin kolaylıkla oluşturulmasını sağladığı için temel mekânsal birim grid olarak belirlenmiş ve

- Yatay ve düşey düzlemlerdeki kullanım çeşitliliği arazi kullanımının ölçülmesinde,

- Nüfus ve yapılaşma yoğunlukları yoğunluğun ölçülmesinde ve

- Farr (2008) tarafından geliştirilen komşuluk birimi tasarım ölçütleri de tasarım kararlarının ölçülmesinde gösterge olarak kullanılmıştır.

Bu göstergeler, sonraki bölümlerde detaylı olarak açıklanan ve çeşitli araştırmacılar tarafından ölçüm için kullanılan göstergelerin detaylandırılmasıyla oluşturulan kavramsal çerçeveden yararlanılarak belirlenmiştir. Çalışmayı başlatan nedenlerin sonuncu maddesinde de belirtildiği gibi önerilen yöntem esnek bir yapıdadır ve farklı amaç, ölçek ve göstergelere sahip çalışmalara da uyarlanabilir. Dolayısıyla geliştirilen yöntem;
- Esnek bir yöntemdir çünkü farklı amaç, ölçek, değişken ve çalışma alanlarına sahip araştırmalara kolaylıkla uyarlanabilir.

- Sayısal bir değerlendirmeye dayandığı için öznel değerlendirmelerin neden olabileceği yanılsamaların önüne geçmektedir.

- Yapılı çevreyi biçimlendiren planlama kararlarının sonuçlarının anlaşılması bakımından mevcut durumu sayısal çerçevede ortaya koyan bir yöntemdir.

\section{Arazi Kullanımına Illişkin Planlama Kararlarının Sonuçlarının Ölçülmesi}

Planlardaki arazi kullanım kararları, kentin yatay düzlemde hangi kullanımlar çerçevesinde biçimleneceğini ifade etmektedir. Ancak arazi kullanımına ilişkin planlama kararlarının bir sonucu olarak kullanım çeşitliliği, kent mekânının yalnızca yatay düzlemde sahip olduğu kullanım türleriyle belirlenemez: yatay düzlemdeki kullanım türlerinin olduğu kadar düşey düzlemdeki kullanım türlerinin de kullanım çeşitliliği konusunda önemli bir rolü vardır (Rowley, 1996; Grant, 2002; Day, 2003; Hoppenbrouwer ve Louw, 2005). Örneğin, planda konut alanı olarak belirlenmiş bir alandaki yapılar birer birer ayrı yapılar olarak düşünüldüğünde, düşey düzlemde kullanım çeşitliliği gösterebilirler. Örnek vermek gerekirse, bir binanın en alt katını bir dükkân, geri kalan katlarını ise konutlar oluşturabilir. Bu yapı sadece konut kullanım türünü barındırmadığından karma kullanımlı olarak kabul edilir. Dolayısıyla, önce yatay düzlemdeki kullanım çeşitliliğinin, sonrasındaysa düşey düzlemdeki kullanım çeşitliliğinin planlama yazınında tanımlanan ölçüm araçları tanıtılacaktır.

\section{Yatay Düzlemdeki Kullanım Çeşitliliğinin Ölçülmesi}

Kullanım çeşitliliğinin kent mekânının yatay izdüşümündeki yansımasını ölçebilmek amacıyla kullanılan ölçüm araçları, bütünleyici ve bölümleyici ölçümler olmak üzere ikiye ayrılmaktadır. Bütünleyici ölçümler, arazi kullanımlarının yalnızca çalışma alanındaki genel dağııımına karşı duyarıı olup, bu kullanımların alan sınırlarındaki dizilimlerine veya genel örüntüsüne karşı hassas değildir. Dolayısıyla, bu ölçümlerin kullanım çeşitliliğinin ölçülmesi sürecinde bazı eksik tarafları bulunmaktadır. Bunlar, aşağıdaki gibi sıralanabilir (Song vd., 20I3):

- Kullanım çeşitliliğinin tespit edileceği çalışma alanındaki küçük ölçekli farklılaşmalara karşı duyarlı değildirler.

- Çalışma alanının büyüklüğüne karşı duyarlıdırlar. Ancak, büyük bir çalışma alanındaki arazi kullanım çeşitliliği küçük bir alana göre daha fazla olabilir. Çünkü büyük bir alanın daha fazla kullanıma ev sahipliği yapması çok daha olasıdır ve dahası, daha büyük bir alan ölçüme konu olmuştur. 
Bu doğrultuda Song vd. (20/3) tarafından, dört adet bütünleyici ölçüm tanımlanmıştır. İlk bütünleyici ölçüm yüzde ve orandır. Çalışma alanındaki belirli bir arazi kullanım türünün diğer arazi kullanım türlerine oranı yüzde ile ölçülmektedir. Bunun yanında, belirli bir arazi türünün farklı mekânsal ölçeklerdeki (ör. ha, $\mathrm{m}^{2}$ vb.) göreli varlığı ise oran ile ölçülmektedir (Song vd., 20।3). Bu çerçevede yüzde ve oran, belirli bir kullanım türünün belirli bir coğrafi alan içerisindeki yoğunluğunun tespit edilmesinde ve genel bir çıkarımın yapılmasında oldukça kullanışlı iki ölçüm aracıdır (Song ve Rodriguez, 2005).

İkinci ölçüm türünü denge indeksi (balance index) oluşturmaktadır. Bu indeks, iki farklı arazi kullanım türünün çalışma alanında birbiriyle dengeli bir şekilde bulunup bulunmadığını ölçmektedir. Bunu yaparken de indeks, I millik ( $1.6 \mathrm{~km})$ mesafedeki istihdam edilen nüfus ve bu nüfusun yakınındaki toplam istihdam sayısı arasındaki ilişkiyle, ticaret etkinliklerinde istihdam edilen nüfus ve hizmet sektörüne ilişkin toplam istihdam sayısı arasındaki ilişkiyi gözetmektedir (Cervero ve Duncan, 2003).

Üçüncü ölçüm türüyse dağıntı indeksidir (entropy index). Arazi kullanımını ilgilendiren çalışmalarda bu indeks, sınırları tanımlanmış bir komşuluk birimi içerisindeki arazi kullanım türlerinin çeşitlilik derecesini ölçmek amacıyla kullanılır. Ancak, küçük ölçekli mekânsal birimler arasındaki geçirgenliği göz ardı ettiği için kullanım çeşitliliğinin ölçülmesinde yetersiz kalabilmektedir (Kockelman, 1997). Bu nedenle bölümleyici ölçümlerde açıklanmış olan benzeşmezlik indeksi geliştirilmiştir.

Dördüncü ölçüm türü Herfindahl-Hirschman indeksidir. Bu indeks, köklerini ekonomik analiz kuramından almaktadır ve bir yoğunlaşma (bir araya gelme) ölçümü olarak tanımlanmaktadır (Manaugh ve Kreider, 20I3).

Bütünleyici ölçüm türlerinin yanı sıra Song vd. (20I3) tarafından altı adet bölümleyici ölçüm tanımlanmıştır. Bunlardan ilkini, tampon bir alan belirlenerek gerçekleştirilen bölümleyici ölçümler oluşturmaktadır. Bu ölçümler diğer ölçümlerle karşılaştırıldığında farklı bir mekân anlayışına sahiptir. Bu anlayışa göre bir hedef nüfus grubu seçilir ve bu gruba belirli bir uzaklıktaki alan, çalışma alanını oluşturan sınırlar olarak belirlenir.

İkinci ölçüm türüyse Atkinson indeksidir. Bu indeks, ekonomi disiplini çerçevesindeki eşitsizlikleri tespit etmek amacıyla Atkinson (1970) tarafından geliştirilmiştir. Atkinson indeksi, transfer ilkesi' (transfer principle) özelliği göstermesiyle Gini kat sayısını andırmaktadır. Ancak Gini kat sayısında olduğunun aksine Atkinson indeksiyle, Lorenz eğrisinde ${ }^{2}$ yer alan farklı noktalardaki mekânsal birimlerin nasıl ağırlıklandırılacağı konusu araştırmacının değerlendirmesine bırakılmıştır (Massey ve Denton, 1988). Bu indeks, komşuluk birimlerini oluşturan sınırlar içerisindeki birim alanlara (grid) farklı ağırlıklar verilebilmesine olanak sağlamaktadır. Böylelikle konut dışı arazi kullanımlarının indeks içerisindeki temsil düzeylerinin, atanan ağılıklar yoluyla ne kadar sağlanacağının belirlenmesine imkân vermektedir. Başka bir deyişle, farklı arazi kullanımlarına farklı ağılıkların verilmesine olanak sağlayarak düzgüsel (normative) bir çıkarım yapılmasına imkân vermektedir (Song ve Rodriguez, 2005).

Üçüncü ölçüm türü kümelenme indeksidir. Bu indeks, göreceli olarak yoğun bir alanda diğer kullanımlardan ayrışan belirli bir arazi kullanım türünün, o alanda ne derecede kümelendiğini gösterir (Song vd., 20l3).

Dördüncü ölçüm türünü benzeşmezlik indeksi (dissimilarity index) oluşturmaktadır. Bu indeks Cervero ve Kockelman (1997) tarafından, sınırları belirli bir alan içerisindeki birim ızgara hücresine düşen farklı arazi kullanımlarının oranı olarak tanımlanmaktadır. Bütün ticaret etkinliklerinin tek bir alışveriş merkezinde toplandığı ve tüm istihdamın tek bir alan içerisinde yer aldığı bir durumda, yakın yerlerde yaşayanların bu kullanımlara yürüyerek ulaşacağından bahsedilebilir. Ancak kullanımların mekânsal çerçevede birbirinden ayrı olduğu bir durumda, bu kullanımların arazide dengeli bir şekilde birbirinden ayrıldığı söylense bile bu kullanımlara daha az yürüyerek ulaşılacağından bahsedilebilir. Bu nedenle, birim alan ölçeğini temel alan bir arazi kullanım çeşitliliği indeksi geliştirilmiştir (Kockelman, 1997).

Beşinci ölçüm türü, etkilenme indeksidir (exposure index). Sosyolojik çerçevede konut etkilenmesi, bir kent içerisindeki sınırları belirli bir coğrafi alanda yaşayan azınlık ve çoğunluk gruplarının, etkileşim içerisine girme ihtimali veya olası etkileşimin derecesine işaret eder. Etkilenme indeksi ayrışmayı salt soyut bir ideal düşünce biçimi olarak eşitlik çerçevesi içinde ölçmek yerine, ortalama bir azınlık ve çoğunluk grubuna ait bir bireyin ayrışma deneyimine göre ölçmeyi anlatır (Massey ve Denton, 1988). Arazi kullanımına ilişkin çalışmalardaysa bu indeks, iki farklı arazi kullanım türünün birbiriyle olabilecek etkileşim derecesiyle ilgilenir (Song vd., 20I3).

Son ölçüm türü Gini indeksidir. Lorenz eğrisinden türetilmiş ve Herfindahl indeksine benzeyen bu indeks, komşuluk birimleri veya metropoliten alanlardaki zaman içerisindeki dağılım değişikliklerinin ve kesitsel karşılaştırmaların gerçekleştirilmesinde kullanışlı bir ölçüm aracıdır. Ancak çok farklı iki dağılım, tamamen aynı Gini indeks değerine sahip olabilmektedir. Sadece tek bir komşuluk birimi için hesaplanan indeks değeri genellikle durumun bütüncül bir çerçevede resmini göstermekte yetersiz kalmaktadır. Elde edilen değerin, farklı komşuluk birimlerinden elde edilen değerlerle karşılaştırılması gerekir (Song ve Rodriguez, 2005).

\footnotetext{
Transfer ilkesi: Bir durum için doğru olan bir söylemin, başka bir durum için de doğru olduğu savına dayanan bir görüştür.

2 Lorenz eğrisinden, genellikle gelir dağılımındaki eşitsizlikleri tespit etmek amacıyla yararlanılmaktadır.
} 
Buraya kadar açıklanan ölçüm türlerinden, ilgili yazında en çok kullanılanlar dağıntı ve benzeşmezlik indeksleridir (bkz. Frank ve Pivo, 1994; Cervero ve Kockelman, 1997; Kockelman, 1997; Srinivasan, 2002; Brown vd., 2009; Yiğitcanlar vd., 20I4). Dolayısıyla, bu indekslerin hesaplanması sırasında ele alınan mekânsal yaklaşım üzerinde durmakta fayda vardır.

Bu çerçevede Kockelman (1997), arazi kullanım türleri arasındaki dengenin dağıntı indeksinin (ortalama dağıntı indeksi olarak da adlandırılmaktadır), çeşitliliğin derecesinin ise benzeşmezlik indeksinin kullanımıyla mümkün olduğunu savunmaktadır. Ortalama dağıntı, sınırları belirli (idari ya da çalışma alanı sınırları) alanlardaki yerleşik alanı oluşturan komşuluk birimi dağıntılarının ortalaması olarak tanımlanmıştır. Buradaki komşuluk birimi tanımını, 800 m'lik yarıçapa sahip her bir yapılı hektar oluşturmaktadır (Şekil la) (Kockelman, 1997).

Dağıntı indeksi, farklı arazi kullanım türlerinin mekândaki dengeli dağılımıyla ilgilenirken, bu kullanımların birbirleriyle olan etkileşimi için farklı bir ölçüm aracına gereksinim duyulmuştur. Bu amaçla Cervero ve Kockelman (1997) benzeşmezlik indeksini geliştirmişlerdir. Bu indeks, her bir yapılı hektardaki arazi kullanımının bu hektarın bitişiğindeki sekiz hektara göre nasıl farklılaştığı ile ilgilenmektedir (Kockelman, 1997). Böylelikle benzeşmezlik indeksi ile arazi kullanım türü çeşitliliğinin tespiti mümkün olmaktadır (Şekil Ib).

\section{Düşey Düzlemdeki Kullanım Çeşitliliğinin Ölçülmesi}

İlgili yazında kentlerdeki kullanım çeşitliliğinin tespit edilmesi sürecinde, yatay düzlemdeki çeşitliliğin belirlenmesi üzerine yapılmış çok sayıda çalışma bulunmaktadır. Ancak düşey düzlemdeki kullanım çeşitliliğinin ölçülmesi üzerine geliştirilmiş çalışma sayısı oldukça azdır. Hâlbuki düşey düzlemdeki kullanım çeşitliliğinin tespit edilmesi, en az yatay düzlemdeki çe-

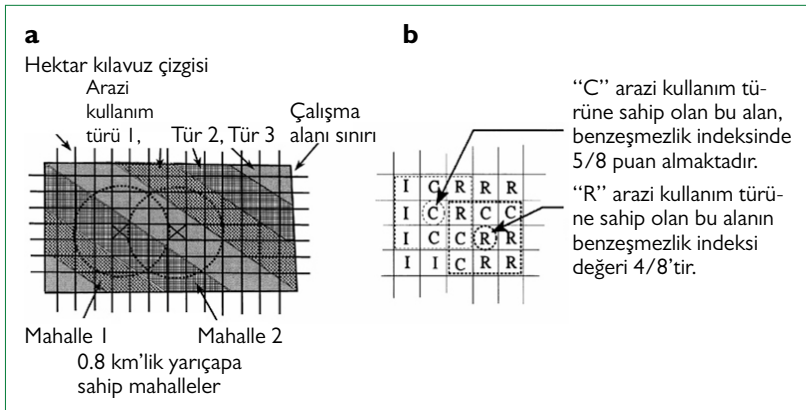

Şekil I. a. Dağıntı indeksi hesabının ele alındı̆̆ı̈rnek alan (Kockelman, 1997) (Ortalama dağıntı indeksinin hesaplanmasında kullanılan formül:

$\sum_{j} \frac{\left[P_{j} \times \ln \left(P_{j}\right)\right]}{\ln J} ; P_{j}: j$. 'ninci kullanım türünün, yapılaşmış alana oranı); $\mathbf{b}$ Benzeşmezlik indeksinin hesabının ele alındığı örnek alan ve basit bir örnek le hesabın açıklanışı (Kockelman ve Cervero, 1997) (Örnekteki harflerin temsil ettiği kullanımlar: C: ticaret (commercial); R: konut (residential; I: sanayi (industrial)). şitliliğin tespit edilmesi kadar önem taşımaktadır. Çünkü bir bütün olarak kullanım çeşitliliğinin ortaya koyulabilmesi için her iki düzlemdeki çeşitlilik değerlerinin tespit edilerek, bu değerlerin bütüncül bir çerçevede ele alınması gerekmektedir.

Cervero ve Kockelman (1997), düşey düzlemdeki kullanım çeşitliliğini birden fazla farklı kullanımın yer aldığı parsel sayısının toplam parsel sayısına oranı olarak tanımlamışlardır. Örneğin zemin katında ticaret üst katlarında konut kullanımı olan bir yapı, birden fazla kullanımın yer aldığı bir parseli işaret eder ve bu doğrultuda düşey düzlemde kullanım çeşitliliğine sahip olduğu söylenebilir. Başka bir deyişle, birden fazla türde kullanıma sahip yapılar düşey düzlemde kullanım çeşitliliğine sahiptir denebilir. Çevremizde genellikle karşılaştığımız konut altı ticaret işlevine sahip yapılar bu sınıflandırmaya girmektedir.

Buna ek olarak, karma kullanımlı yapılarda bulunan kullanım türlerinin oranı farklı kullanım tipolojilerinin belirlenmesi ve böylelikle de karma kullanımlı yapıların çeşitliliğinin tespit edilmesi açısından önemlidir. Konut altı ticaret işlevine sahip bir yapı düşey düzlemde kullanım çeşitliliğine sahiptir ancak zemin katı ticaret, ikinci katı ofis, geriye kalan katları konut kullanımındaki bir yapı bir öncekine göre daha fazla kullanıma sahip olduğundan daha çeşitlidir denebilir.

\section{Yoğunluğa İlişkin Planlama Kararlarının Sonuçlarının Ölçülmesi}

Kenti ilgilendiren çalışmalarda birim alan başına düşen nüfus veya yapılaşma miktarını ifade eden yoğunluk (Dovey ve Pafka, 20।4; Pont ve Haupt, 20I0), farklı disiplinlerde farklı çerçeveler içerisinde ele alınan bir kavramdır. Bu doğrultuda, Newman ve Hogan (198I) yoğunluğun ele alınış biçimini iki ana yöntemle incelemiş ve bunları, insan odaklı ve fiziksel odaklı yöntemler olarak adlandırmışlardır (Tablo 3).

Planlama çok disiplinli bir çalışma alanı oluşturduğundan, Tablo 3'te belirtilen ve kentsel yoğunluk kavramıyla ilişkisi kurulan çoğu konuyla ilgilenir. Mekânı tanımlayan ve sınırları belirli bir alan içerisindeki farklı yoğunluklar planlamada kullanılmak üzere o alana ilişkin fikir verecektir. Bu çerçevede Pont ve Haupt (2010) yoğunluğu, algılanan yoğunluk ve fiziksel yoğunluk olmak üzere iki ana başlık altında incelemişlerdir. Planlama daha çok fiziksel yoğunlukla ilgilenmektedir, ancak algılanan yoğunluktan da bahsetmekte fayda vardır. Çünkü planlama sürecinde insanların algıladığı yoğunluk değerleri de bu süreçte önemli bir girdidir. Bu doğrultuda, bir bireyin yoğunluk algısı rakamlarla anlatılan değerlerden çok farklı olabilir. Bunun nedeni de çoğu zaman bireysel ve kültürel farklılar olabilmektedir (Pont ve Haupt, 2010). Benzer şekilde Churchman'a (1999) göre algılanan yoğunluk; bir kişinin sınırları belirli bir alanda algıladığı insan sayısı, mekânın kullanılabilirliği ve mekân örgütlenmesi hakkındaki genel yargısını ifade eder ve burada 
Tablo 3. Farklı disiplinler tarafından yoğunluğun ele alınış biçimleri (Newman ve Hogan, I98I'den düzenlenerek oluşturulmuştur)

\section{Yoğunluğun ele alınış biçimleri}

\begin{tabular}{|c|c|c|c|}
\hline \multicolumn{2}{|c|}{ İnsan odaklı yöntemler } & \multicolumn{2}{|c|}{ Fiziksel odaklı yöntemler } \\
\hline Etoloji & $\begin{array}{l}\text { Artan kentsel yoğunluğun; psikolojik } \\
\text { baskı ve suçların artmasına sebep olup } \\
\text { olmadığıyla ilgilenir. }\end{array}$ & Ekoloji & $\begin{array}{l}\text { Artan kentsel yoğunluğun; olumsuz } \\
\text { çevre koşulları oluşturup oluşturma- } \\
\text { dığıyla ilgilenir. }\end{array}$ \\
\hline Sosyoloji & $\begin{array}{l}\text { Artan kentsel yoğunluğun; suç, intihar } \\
\text { ve uyuşturucu madde kullanımı, olumsuz } \\
\text { sağlık koşullarının oluşumu ve kırsal } \\
\text { yaşam biçimlerinin unutulmasına neden } \\
\text { olup olmadığıyla ilgilenir. }\end{array}$ & Ekonomi-Coğrafya & $\begin{array}{l}\text { Artan kentsel yoğunluğun; ulaşım } \\
\text { maliyetlerini, özellikle enerji tüketiminin } \\
\text { azalacağı varsayımı çerçevesinde azaltacağı } \\
\text { yönünde geliştirilmiş görüşlerle ilgilenir. }\end{array}$ \\
\hline Psikoloji & $\begin{array}{l}\text { Artan kentsel yoğunluğun psikolojik } \\
\text { baskı yaratıp yaratmadığıyla ilgilenir. }\end{array}$ & Ulaşım mühendisliği & $\begin{array}{l}\text { Artan kentsel yoğunluğun; yeşil ulaşım } \\
\text { türlerini özendireceği, enerji tüketimini } \\
\text { azaltacağı, altyapı maliyetlerini düşüreceği } \\
\text { ve çevresel kaliteyi artıracağı yönünde } \\
\text { geliştirilen görüşlerle ilgilenir. }\end{array}$ \\
\hline
\end{tabular}

açıklanan algı kavramı öznel bir durumu betimler. Çünkü algı, kişiden kişiye farklılık gösterebilecek bir kavramdır.

Diğer taraftan Alexander (1993), yoğunluğun insan hayatını nasıl etkilediğine işaret eden üç kavramdan bahsetmektedir ve bunları yoğunluk, algılanan yoğunluk ve kalabalık olarak sıralamaktadır. Yoğunluk ve algılanan yoğunluk kavramlarına ilişkin tanımlara ek olarak kalabalık, bir kişinin yoğunluk ve algılanan yoğunluk çerçevesinde olumsuz yargıda bulunduğu bir durumu ifade eder. Algılanan yoğunluk kavramında olduğu üzere bir kavram olarak kalabalık da bireylerin öznel değerlendirmeleri sonucunda ortaya çıkan bir ifade olarak tanımlanabilir (Churchman, 1999).

Yoğunluğun tespiti için kullanılan çok sayıda ölçüm aracı bulunmaktadır. Bunlar; taban alanı kat sayısı, hane yoğunluğu, kişi yoğunluğu, konut yoğunluğu, net yoğunluk, brüt yoğunluk, fiziksel yoğunluk, ölçülmüş yoğunluk, algılanan yoğunluk, iç yoğunluk, mekânsal yoğunluk, sosyal yoğunluk vb. olarak sıralanabilir (Boyko ve Cooper, 20II; Dovey ve Pafka, 20I4). Yoğunluğun uluslararası ölçekte kabul edilmiş ortak bir ölçüm aracı bulunmamaktadır. Yoğunluk ölçüm araçları ülkeden ülkeye, kültürden kültüre ve hatta bir kentten başka bir kente farklılık gösterebilmektedir. Ancak genellikle, yoğunluk ölçümleri genel kabul görmüş birkaç ölçüm aracının kullanılmasıyla gerçekleştirilir. Örneğin, bazı ülkelerde yoğunluk birim alandaki kişi sayısıyla ifade edilirken; bazı ülkelerdeyse birim alandaki hane sayısıyla ölçülmektedir. Bunların yanı sıra, buradaki yoğunluk hesabında açılanan birim alan farklı birimlerle ifade edilebilir. Bu kapsamda ilgili yazında en çok kullanılan alan birimleri; İngiliz dönümü (acre), hektar, mil kare ve kilometre kare olarak sıralanabilir. Ayrıca, net ve brüt yoğunluklar söz konusu olduğunda, uluslararası ölçekte ortak bir tanım geliştirilmiş olmasına rağmen bazı ülkelerde bu yoğunlukların farklı tanımları olabilmektedir (Churchman, 1999).

Bu bilgilere ek olarak planlama disiplini çerçevesinde yoğunluk, genel anlamda iki kavram çerçevesinde ele alınmaktadır ve bunlar; nüfus ve yapılaşma yoğunluklarıdır.

\section{Nüfus Yoğunluğu}

Churchman (1999) yoğunluk ölçüm araçlarını dört ana başılı altında incelemiştir. Bunlar; net parsel yoğunluğu, net yoğunluk, brüt yoğunluk ve diğer ölçüm araçlarıdır. Parsel yoğunluğu, konutlar için geliştirilmiş alanlarda hesaplanmaktadır ve genellikle birim alana düşen hane sayısı ve birim alandaki kat alanları toplamı yardımıyla hesaplanmaktadır. Net yoğunluk, konutlara hizmet götüren kamuya ait yolları da hesaplamaya katmaktadır. Bu yoğunluk türünün hesaplanması hane sayısının, parsel alanına ek olarak yolların yarısının da dâhil edilmesiyle elde edilen değere bölünmesiyle gerçekleştirilir. Diğer bir taraftan brüt yoğunluk, kamusal ve özel alanların bir araya gelmesiyle oluşan bir konut alanında yaşayan insan yoğunluğunu ifade etmek amacıyla kullanılır. Diğer ölçüm araçları kapsamındaysa nüfus yoğunluğunu ölçmeye yönelik bir diğer araç ele alınmıştır. Bu ölçüm türünde, yerleşik alanın tamamı hesaplama aşamasında kullanılan paydayı oluşturmaktadır. Bu nedenle, şimdiye kadar bahsedilen ölçüm 
türleri arasında en düşük yoğunluk değerinin elde edileceği ölçüm türü, bu ölçüm türüdür (Churchman, 1999).

\section{Yapılaşma Yoğunluğu}

Sınırları belirli bir birim alan içerisinde gerçekleştirilmiş toplam inşaat alanı, yapılaşma yoğunluğunu vermektedir. Yapılaşma yoğunluğunun tespiti için Türkiye'deki planlama pratiğinde kat alanı kat sayısı (KAKS) ve taban alanı kat sayısı (TAKS) kullanılmaktadır. KAKS, bir parsel üzerinde kaç metrekare inşaat yapılabileceğini; TAKS ise bir parselin ne kadarının yapılaşmaya açılabileceğini ifade etmektedir (Bölen vd., 2009).

Bu bilgilerin yanı sıra, yoğunluğun tespiti aşamasında kullanılacak ölçüm aracının seçiminde, üzerinde çalışılacak alan sınırlarının büyüklüğü (ölçeği) önemlidir. Çünkü kullanılacak ölçüm aracı, çalışmanın amacına ve çalışma alanının ölçeğine göre değişmektedir. Yoğunluk ölçümünün gerçekleştirilebileceği olası mekânsal ölçekler Şekil 2’deki gibidir (Taylor ve Nostrand, 2008).

Şekil 2'deki ölçeklere göre kullanılacak ölçüm aracı değişeceği gibi, net veya brüt ölçümler de değişecektir. Net yoğunluk genellikle küçük ölçekli mekânsal yoğunluk tespiti çalışmalarında kullanılır ve kentsel çalışmalarda kullanılan en küçük ölçekli mekânları genellikle parseller oluştururlar. Parsel sınırlarından mahalle, semt veya daha büyük ölçekli sınırlara doğru gidildiğinde mekândaki farklılık da artmaktadır. Bir başka

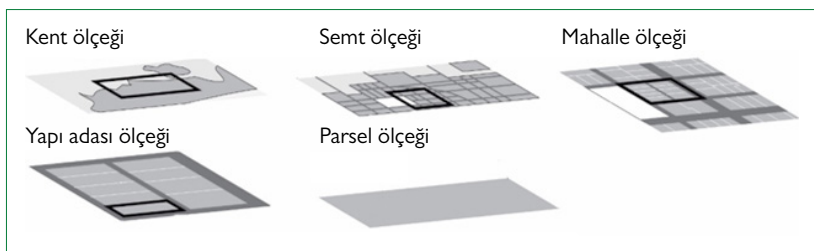

Şekil 2. Çalışma alanının ölçeğine göre yoğunluk ölçüm araçları değişmek tedir (Taylor ve Nostrand, 2008). deyişle, arazi kullanım çeşitliliği de arttığından (özellikle kamu kullanımına açık alanların varlığı arttığı için) net yoğunluk ölçümü zorlaşmaktadır. Bu durum da ölçümün duyarlılık düzeyini azaltmaktadır. Şekil 3'te net ve brüt alanlar arasındaki fark gösterilmektedir Taylor ve Nostrand, 2008).

Yoğunluk değerleri çalışılan alanın ölçeğine göre değişebileceği gibi farklı konut tipolojilerinin yer aldığı aynı büyüklükteki sınırlara sahip alanlar için de farklılık gösterebilmektedir. Dovey ve Pafka (20।3), tanımladıkları dört farklı kentsel tipoloji için farklı yoğunluk değerleri elde etmişlerdir (Şekil 4).

Bu bilgilere dayanarak yoğunluğun tespiti için seçilecek ölçüm aracının çalışmanın amacı, çalışma alanının büyüklüğü (ölçeği) ve alanı oluşturan kentsel tipoloji öğeleri dikkate alınarak çok yönlü bir süzgeçten geçirildikten sonra seçilmesi gerektiği açık bir şekilde söylenebilir.

\section{Komşuluk Birimi Tasarımına İlişkin Planlama Kararlarının Sonuçlarının Ölçülmesi}

Bu bölümde, komşuluk birimlerini ${ }^{3}$ oluşturan ve planlama sürecinde ele alınan tasarım ölçütlerinin çeşitli araştırmacılar tarafından nicel çerçevede nasıl ele alındığı incelenecektir. Ancak bu incelemeye başlamadan önce, komşuluk birimi tasarım ölçütlerinin geçmişten günümüze nasıl bir gelişim süreci geçirdiği üzerinde durmakta fayda vardır.

Komşuluk birimi; sınırları belirli bir coğrafi alanda yaşayan, yerel yönetimler tarafından sağlanan hizmetleri paylaşan ve belirli bir derecede birbirine bağlılık duygusu besleyen insanların bir araya gelerek yaşadığı kentsel mekânlara verilen isimdir. Bu doğrultuda komşuluk birimlerini tanımlayan üç anahtar sözcükten bahsedilebilir. Bunlar; insanlar, mekân ve bağlılıktır. Bu üçü arasında mekân, bir komşuluk biriminin diğerinden ayırt edilebilmesini sağlayan en fark edilebilir sözcüktür (Park ve Rogers, 20I5).

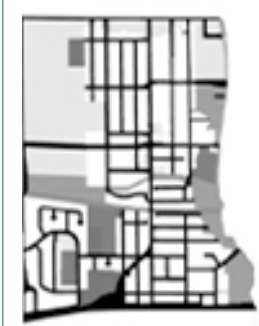

Kent dokusu farklı arazi kullanımlarından oluşur.

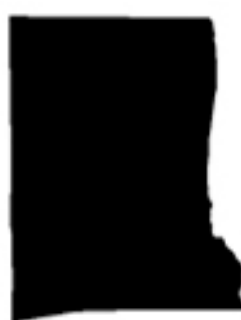

Brüt alan bütün arazi kullanımlarını içerir.

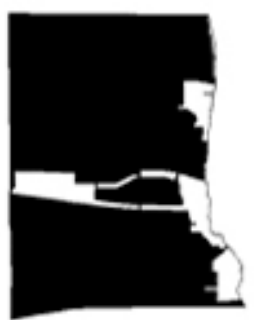

Kent dokusu yapılaşmaya uygun alan ve yapılaşmaya uygun olmayan alan olmak üzere ikiye ayrılır.

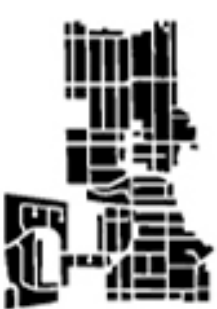

Net konut parseli alanı, konut parselleri için ayrılmış yapılaşmaya uygun alanları temsil eder. Bu alanlar içerisinde yollar, parklar vb. yapılaşmamış alanlar yer almaz.

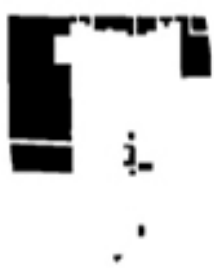

Net istihdam parseli alanı, iş yerlerinin oluşturduğu yapılaşmış alanları temsil eder. Bu alanlar içerisinde yollar, parklar vb. yapılaşmamış alanlar yer almaz.

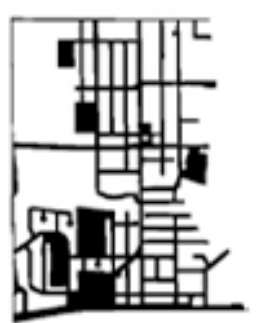

Kamusal arazi kullanımları, park, yol, okul, ibadet alanı vb. yapılaşmış alanlarından oluşur.

Şekil 3. Kentsel doku ve net-brüt yoğunluk ilişkisi (Taylor ve Nostrand, 2008).

\footnotetext{
3 Komşuluk birimi ve mahalle, genellikle birbirinin yerine kullanılmaktadır.
} 


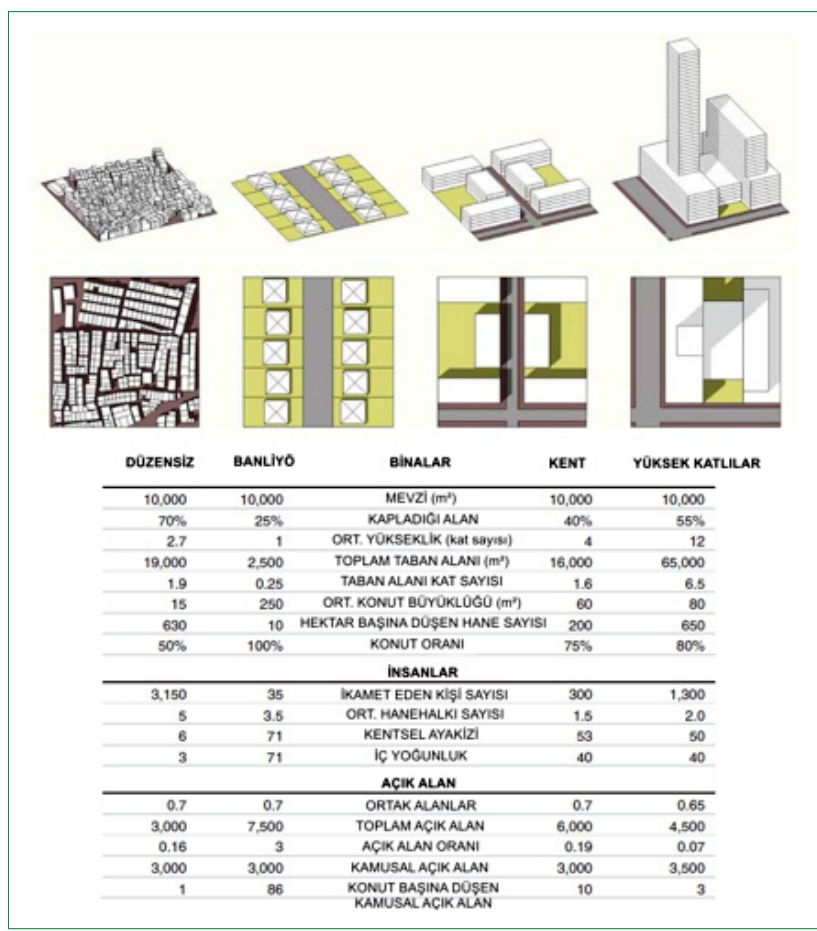

Şekil 4. Farklı kentsel tipolojiler ile yoğunluk ilişkisi (Dovey ve Pafka, 2013).

Planlamada tasarım ölçütleri yerleşim alanının ölçeğine göre belirlenmektedir. Kent ölçeğindeki tasarım ölçütleriyle komşuluk birimi ölçeğindeki ölçütler birbiriyle örtüşebileceği gibi genellikle de birbirinden ayrılmaktadır. Bu çerçevede, komşuluk birimi ölçeğinde tasarım ölçütlerinin temelini oluşturan bazı noktalar bulunmaktadır. Bunların en önemlilerinden birini günümüzde önemini yitirmeye yüz tutmuş bir kavram olan kamusal alanlara erişim uzaklığı oluşturmaktadır. Bu kapsamda ilköğretim okullarına erişim özellikle önemlidir çünkü mahalledeki çocukların yürüme uzaklığı içinde bulunan okullarına yorulmadan ve güvenli bir şekilde erişebilmeleri gerekmektedir. Bunun yanı sıra, mahallelinin günlük ihtiyaçlarını temin edebileceği market, bakkal, terzi, eczane vb. küçük ölçekli ticari işletmelerin varlığı da önemlidir. Erişim ve alışveriş olanaklarının yanı sıra mahallelinin birlikte vakit geçirebileceği park, meydan vb. kamusal açık alanların varlığı da önemlidir.

Komşuluk birimi tasarımı olgusu, İngiltere kökenli Bahçe Kent kavramından temellerini almışır. Ebenezer Howard'ın geliştirdiği Bahçe Kent önerisinde her bir yerleşim birimi, 5000 kişilik bir nüfusa hizmet edecek bir ilkokul çerçevesinde şekillendirilmiştir. Sıkışık kent merkezini rahatlatmak amacıyla geliştirilmiş Bahçe Şehir akımından esinlenerek, komşuluk birimi tasarımı olgusunu kuvvetlendiren iki farklı tasarım akımından bahsedilebilir. Bunlar 1920'li yıllarda geliştirilmiş olan "Sunnyside Gardens" ve "Radburn" akımlarıdır (Silver, 1985). Dolayısıyla Perry'nin komşuluk birimi kavramını geliştirirken döneminin önde gelen isimlerinden etkilendiği söylenebilir. Ancak Perry komşuluk birimi kavramını geliştirirken, en fazla, yaşadığı yer olan Forest Hills Gardens'tan etkilenmiştir. Burada yaşarken saptadığı güçlü ve zayıf yönler geliştirdiği komşuluk birimi kavramının temel taşlarını oluşturmuştur. Perry, Forest Hills Gardens'ın kendine ait bir okulunun bulunmasını benimsemiş, ancak kamusal kullanımların iş yerlerinden ayrılarak çeper yerine merkezde yer almaları gerektiğini düşünmüştür (Rohe, 2009). Perry tarafindan geliştirilen ve bir komşuluk biriminin sahip olması gereken altı ilke Tablo 4'te gösterilmektedir (Perry, 1929).

Komşuluk birimi kavramının güncellenmesi gerektiğine ilişkin görüşler Yeni Şehircilik akımlarının doğrultusunda gelişmiştir. Bu akımlara; Geleneksel Komşuluk Birimi Gelişimi (Traditional Neighborhood Development), Ulaşım Odaklı Gelişim (Transport Oriented Development) ve Köy Kent (Urban Village) örnek ve-

Tablo 4. Clarence Perry (1929) tarafından geliştirilen ve komşuluk birimi tasarımını yönlendiren ilkeler

\section{Komşuluk birimi tasarımını yönlendiren ilkeler}

I. Büyüklük Komşuluk birimi, bir ilköğretim okulunun hizmet edeceği nüfus düşünülerek planlanmalı ve alan sınırları da
nüfus yoğunluğuna göre belirlenmelidir.

2. Sınırlar

Komşuluk birimini oluşturan sınırlar, ana caddeler tarafından sarılmalı ve trafik mahalle içine girmeden bu caddelerden akmalıdır.

3. Açık alanlar

Küçük parklar ve eğlence-dinlence alanlarından oluşan bir sistem planlanmalıdır.

4. Kurum - kuruluş alanları Okul ve diğer kurum veya kuruluşlar, çepere de en iyi hizmeti verebilecek şekilde, komşuluk biriminin merkezi bir noktasında yer almalıdır.

5. Yerel dükkânlar Komşuluk birimi nüfusu için yeterli bir veya birden fazla alışveriş alanı, mahallenin çeperinde ve tercihen kavşakların yanında, diğer komşuluk birimlerinin de yararlanabileceği düşünülerek yer almalıdır.

6. İç Sokak sistemi İç sokak sistemi, komşuluk birimi içerisinde kolay ulaşımı sağlayacak nitelikte olup; yoğun trafiği komşuluk birimi içine almayacak şekilde planlanmalıdır. 


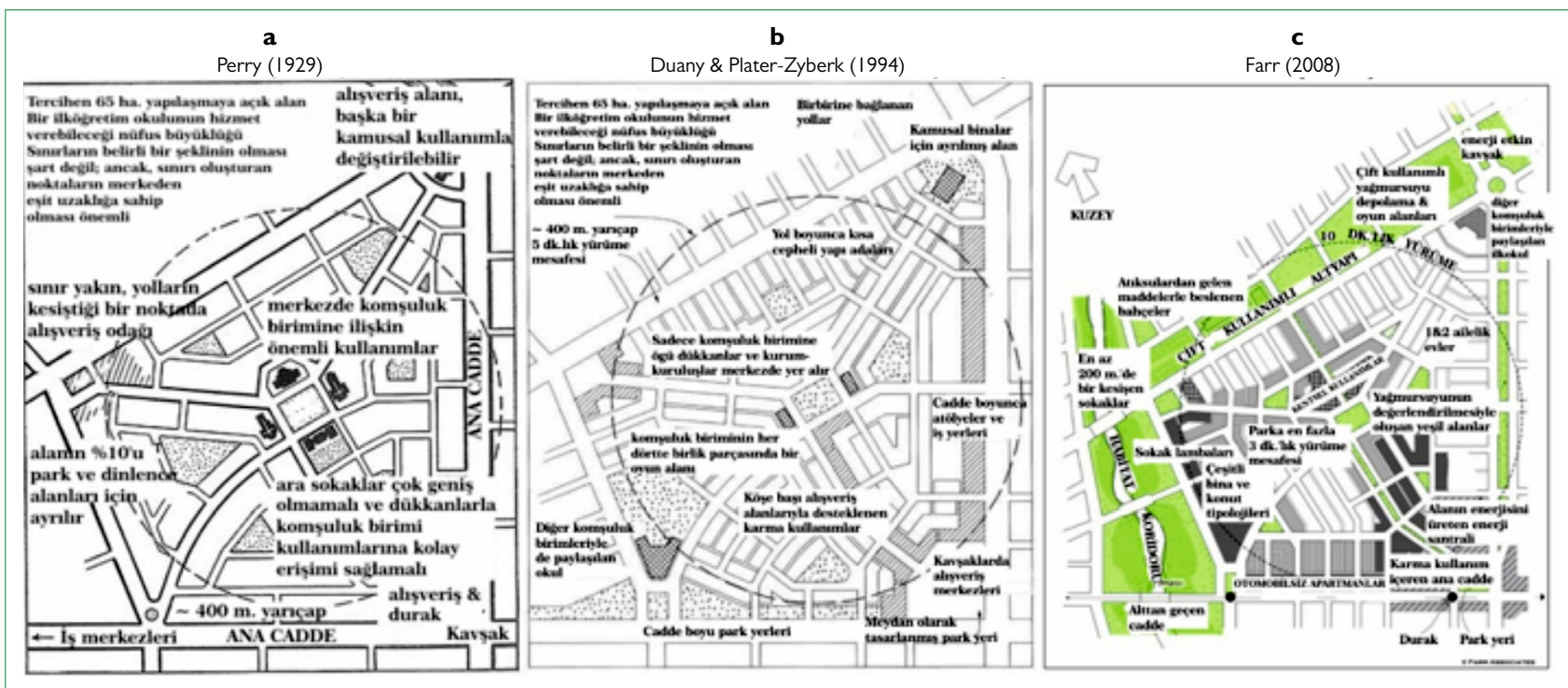

Şekil 5. a. Perry tarafından geliştirilen komşuluk birimi; b. Duany ve Plater-Zyberk tarafından, ilgili dönemlerin dinamikleri de ortaya konarak geliştiren komşuluk birimi; c. Yeni Şehircilik akımını benimsemiş Farr’ın güncellediği komşuluk birimi kavramı (Farr, 2008).

rilebilir (Park ve Rogers, 2015). Bu akımlar doğrultusunda geçmişten günümüze şekillenen komşuluk birimleri Farr (2008) tarafından üç dönemsel çerçevede ele alınmıştır (Şekil 5). Bu dönemlerden ilki, Perry'nin 1929 yılında geliştirdiği komşuluk birimi kavramına dayanmaktadır (Şekil 5a). İkincisiyse, Duany ve Plater-Zyberk tarafından 1994 yılında geliştirilen komşuluk birimi kavramına dayanmaktadır. En son dönemse, Perry ve Duany ve Plater-Zyberk'in geliştirdiği kavramların üzerine günümüz yorumunu ekleyen Farr (2008) tarafından şekillenmiştir.

Şekil 5'ten de anlaşılacağı üzere Duany ve Plater-Zyberk, Perry'nin geliştirdiği komşuluk birimi kavramında da olduğu gibi beş dakikalık yürüme mesafesini, yaklaşık 400 metrelik yarıçapı ve merkezde toplu taşım duraklarını, araç park yerlerini ve bir okulun varlığını benimsemiştir (Farr, 2008). Açmak gerekirse, Duany ve Plater-Zyberk (1994) bir komşuluk biriminin sahip olması gereken özellikleri aşağıdaki gibi sıralamıştır (ayrıca bkz. Şekil 5b):

- Bir merkez ve bir sınıra sahip olmalıdır.

- Büyüklüğü, merkez ve çeper arasındaki uzaklık dikkate alındığında 400 metreyi geçmemelidir.

- Sınırları içerisinde kullanım dengesi sağlanmalıdır. Konut, alışveriş, iş yeri, okullar, ibadet alanları ve eğlence - dinlence alanları arasındaki denge sağlanmalıdır.

- Komşuluktaki sokak ağı birbirini kesmeli, çıkmaz sokak yaratılmamalıdır. Birbirini kesen sokak ağı, yapılaşma alanlarına hizmet götürmeli ve trafiğin akışını sağlamalıdır.

- Konut dışı kullanımların yer seçiminde kamusal kullanımlar öncelikli ele alınmalıdır.

Günümüze yaklaşıldı̆̆ında, Yeni Şehircilik akımını benimsemiş araştırmacılardan olan Farr, Perry ve Duany ve Plater-Zyberk tarafından geliştirilmiş komşuluk birimi kavramlarına ufak eklemeler yapmıştır. Farr (2008) tarafından önerilen komşuluk biriminin ortalama büyüklügü yaklaşık 4000 metrekaredir (0.4 ha). Benzer olarak, komşuluk biriminin yarıçapı yaklaşık 400 ila 500 metre arasındadır. Ancak geliştirilen komşuluk birimi önerilerinden farklı olarak Farr, bir ortaokul veya ilkokulun varlığını, komşuluk birimi için olmazsa olmaz bir kullanım olarak görmemiştir.

Bunlara ek olarak Farr, bir komşuluk biriminin sahip olması gereken diğer özellikleri aşağıdaki gibi sıralamıştır (Calgary Bölgesel Ortaklığı, 20II) (ayrıca bkz. Şekil 5c):

- Çok işlevli bir açı/yeşil alan komşuluk birimi içerisinde bir eksen oluşturmalıdır.

- Yağmur suyu yönetimine ilişkin altyapı kullanımları (yağmur bahçeleri gibi) yol altyapısıyla bütünleştirilmelidir.

- Açık/yeşil alan ağı, yaya ulaşım ağının bir parçasını oluşturmalı ve kamusal eğlence-dinlence amaçlarına hizmet etmelidir.

Yukarıda sıralanan özelliklerin yanı sıra geliştirdiği komşuluk birimi kavramının biçimsel çerçevede sahip olması gereken özellikleri Farr (2008), beş temel yapı taşı altında incelemiştir (ayrıca bkz. Tablo 2). Bunlardan ilkini tanımlı merkez ve sınır oluşturmaktadır. Farr'a göre bir kişi komşuluk birimi sınırlarına girdiğinde bu sınırlarla birlikte alana girdiğini de anlamalıdır. Aynı şekilde merkezin de merkezi kullanımlarla algılanması gerekmektedir. İkincisini, yürünebilir büyüklük oluşturmaktadır. Farr, çoğu kişi için otomobil veya bisiklet kullanmak yerine yürüyüşün tercih edildiği uzaklığı yaklaşık 400 metre olarak tanımlamaktadır ve bu uzaklığın, alanın topoğrafik özelliklerine göre azalabileceğini belirtmektedir. Üçüncü özelliğiyse, 
alışveriş olanaklarına sahip ve konut alanlarına yakın iş yerleri içeren karma arazi kullanımları ve konut türlerinin varlığı oluşturmaktadır. Farr, komşuluk biriminde farklı kullanımların yer almasıyla yaşayanların eğlence, spor, alışveriş vb. günlük etkinliklerini o alan içerisinde gerçekleştirebileceğini öne sürer. Konut türünün farklılaşmasıyla da farklı gruplardaki (gelir, yaş, etnik köken vb.) insanların bir arada yaşamalarının mümkün olduğunu belirtir. Dördüncü özellik, birbirine bağlı ve yürünebilir sokak örüntüsüdür. Farr, bu örüntüde bir yapı adasının kenar uzunluğunun 180 metreyi geçmemesi gerektiği üzerinde durur. Böylelikle erişilebilirliğin artmasında küçük yapı adalarının ve sık bir şekilde konumlandırılmış olan kavşakların varlığının önemli olduğundan söz eder. Son özellikse, kentsel kullanımların varlığından oluşur. Farr, kentsel kullanımlar ile oluşturulan odakların, alan içerisinde yaşayan herkes tarafından erişilebilir olması gerektiğinden ve bu nedenle kullanımların yürüme uzaklığı içinde yer alması gerektiğinden bahseder (Şekil 6).

Yeni Şehircilik akımı ile komşuluk birimi tasarımını yönlendiren diğer ilkeler aşağıdaki gibi sıralanabilir (Yeni Şehircilik Kongresi, 200I):

- Komşuluk birimleri derişik, yaya dostu ve karma kullanımı destekleyici nitelikte olmalıdır.

- Günlük yaşantıdaki pek çok etkinlik, özellikle yaşlılar ve çocuklar gibi özel araç kullanamayanlar için yürüme uzaklığı içinde kalan yerlerde sürdürülmelidir. Birbiriyle bağlantılı sokak örüntüsü, yürümeyi destekleyici ve otomobillerle yapılan yolculuk sayılarını ve mesafelerini azaltıcı nitelikte olmalıdır.

- Komşuluk birimlerinde farklı yaş ve gelir gruplarının bir arada yaşayabilmesini sağlamak amacıyla konut türlerinin çeşitliliği sağlanmalıdır. Böylelikle, farklı gruplardan insanların günlük yaşantıda bir araya gelmeleri ve kişisel ve toplumsal bağlarını güçlendirmeleri mümkün olacaktır.

- Toplu taşıma duraklarına yürüme uzaklığında olan alanlarda belirli bina yoğunluklarıyla desteklenen arazi kullanımlarının gelişimi, otomobil kullanımına yönelik yaşayabilir bir alternatif geliştirecektir.

- Kentsel, kurumsal ve ticari etkinlikler komşuluk birimleri ve semtler ölçeğinde yoğunlaştırılmalı, uzak ve tek başına kalmış tekil arazi kullanımları şeklinde kurgulanmamalıdır. Okullar, çocukların yürüyerek veya bisikletle erişebileceği bir konumda yer almalıdır.

- Küçük ölçekli çocuk parklarından büyük ölçekli kent parklarına kadar parkların mekândaki etkin dağılımı sağlanmaıdır. Koruma alanlarıyla açık alanlar mutlaka tanımlanmalı ve farklı komşuluk birimleri veya semtleri birbirine bağlamalıdır.

Amerikan Planlama Derneği'nin "iyi komşuluk birimleri” için geliştirdiği yönlendirici ilkeler ve özellikler ise (komşuluk birimi biçimi ve bileşenleri doğrultusunda) Tablo 5 'te gösterilmiştir (Amerikan Planlama Derneği, 2017).

Bu doğrultuda, şimdiye kadar geliştirilen ve tarih boyunca değişim gösteren komşuluk birimi tasarım ölçütlerinin nicel çerçevede genellikle benzerlik gösteren özellikleri aşağıdaki gibi sıralanabilir:

I. Yürüme mesafesi topoğrafik özelliklerin zorluk yaratmadığı durumlarda (yokuş vb.) genellikle 400-500 metre arasında bir mesafe olarak tanımlanmıştır. Bu mesafe, farklı kullanımlara kolay erişebilme ve komşuluk birimi sınırlarının tanımlanabilmesi bakımından önemlidir.

2. Komşuluk biriminde kullanım çeşitliliği sağlanmalıdır. Bu, günlük hizmet ve kullanımlara kolay bir şekilde erişmekte önemlidir. Çeşitliliğin ölçüm yolları, kullanım çeşitliliğinin ölçülmesi bölümünde açıklanmıştır.

3. Sokaklar birbirini erişimi zorlaştırmayacak bir biçimde kesmeli (başka bir deyişle, kısa cepheli yapı adaları tanımlanmalı, 180 metreye kadar) ve çıkmaz sokaklar yaratılmamalıdır.

\section{Yapılı Çevreyi Biçimlendiren Planlama Kararları Sonuçlarının Ölçülmesine İlişkin Yöntem Önerisi}

Bu çalışmada, varsayımsal bir komşuluk birimi örneği üzerinde arazi kullanımı, yoğunluk ve komşuluk birimi tasarımı çerçevesindeki planlama kararlarının mekândaki yansımasının (bkz. Tablo 2), sayısal çerçevede nasıl ortaya konacağına ilişkin bir yöntem önerilmiştir. Planlama kararları doğrultusunda biçimlenen yapılı çevrenin nicel değerler çerçevesinde değerlendirilmesi sürecinde önerilen bu yöntemde sırasıyla arazi kullanım çeşitliliği, yoğunluk ve komşuluk birimi tasarım ölçütleri, her biri

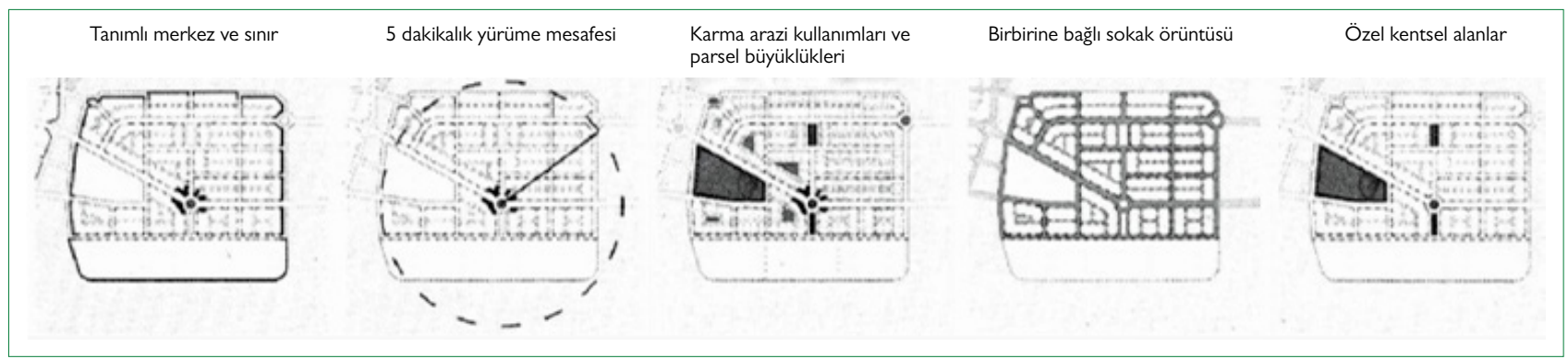

Şekil 6. Farr tarafından geliştirilen komşuluk birimi kavramının sahip olması gereken beş temel özellik (Farr, 2008). 
Tablo 5. İyi bir komşuluk biriminin sahip olduğu özellikler ve iyi bir komşuluk biriminin yaratılması aşamasında yönlendirici ilkeler (Amerikan Planlama Derneği, 2017)

\section{İyi bir komşuluk biriminin sahip olduğu özellikler}

I. Mahallelinin günlük yaşantısına katkıda bulunacak çeşitli işlevsel nitelikleri barındıran alanlara sahip olmalıdır (konut, ticaret veya karma kullanım).

2. Farklı ulaşım türlerini destekleyici nitelikte olmalıdır (yayalar, bisikletliler, özel araç kullanıcıları vb. için).

3. Görsel olarak ilgi çekici tasarım ve mimari özelliklere sahip olmalıdır.

4. İnsan ilişkilerini ve sosyal etkinlikleri özendirici olmalıdır.

5. Mahallelinin katılımcılığını özendirmeli ve güvenli bir çevre sağlamalıdır.

6. Sürdürülebilirliğe katkı sağlamalı ve iklim değişiklï̆i nedenli taleplere cevap verebilmelidir.

7. Hatırlanmaya / anılmaya değer bir karaktere sahip olmalıdır.

\section{İyi bir komşuluk birimi için yönlendirici ilkeler}

\section{Komşuluk birimi formu ve bileşenleri}

- Komşuluk birimi, kolaylıkla fark edilebilen bir konumda mı? Sınırları tanımlı mı?

- Komşuluk birimi, bulunduğu konum üzerindeki doğal şartlara ve yakın çevresine uyum sağlayabilmiş mi?

- Komşuluk birimi içindeki farklı kullanımların birbirine uzaklığı ne kadar? Bu kullanımlar yürünebilir veya bisikletle ulaşılabilir mesafelerde mi? Yürüyerek veya bisiklete binerek komşuluk birimi içerisindeki farklı kullanımlardan yararlanabilmek mümkün mü?

- Komşuluk birimi, sosyal etkileşimi destekler nitelikte mi? Mahalleli bilinci mevcut mu?

- Komşuluk birimi güvenli bir ortam yaratıyor ve güvenli olarak algılanabiliyor mu? Sokaklar çocuklar ve diğer kullanıcılar için güvenli mi?

- Binaların ölçekleri birbiriyle uyumlu mu?

için ayrı ayrı mekânsal indeksler geliştirilerek ölçülecektir. Son aşamadaysa önceki aşamalardan elde edilen indeks değerleri bir araya getirilecektir. Yöntemin uygulanışına geçmeden önce şunu belirtmek gerekir ki bu yöntem coğrafi bilgi sistemleri (CBS) ortamındaki mekânsal analiz ve cebir araçları kullanılarak oldukça kolay bir şekilde farklı çalışma alanlarına uygulanabilir.

Bu bilgiler ışığında, varsayımsal komşuluk biriminin sahip olduğu mekânsal özellikler ve bu komşuluk birimi hakkında bilinenler aşağıdaki gibidir (unutulmamalıdır ki bu özellikler farklı çalışmalarda değişkenlik gösterebilir, burada açıklanacak örnekteki varsayımlar aşağıdaki gibidir):

- Büyüklüğü 9 hektardır ve kare şeklindedir,

- Konut, ticaret ve kamu kullanımları barındırmaktadır,

- Yapı ölçeğinde;

- kullanım türleri (konut, ticaret vb.) ve sayıları,

- hane sayıları,

- kat sayıları ve

- taban alanları bilinmektedir.

Bu çerçevede, birim alanlardan (grid) faydalanılarak yapılı çevrenin her bir bileşeni için farklı mekânsal indeksler oluşturulacaktır ve mekânsal indekslerin geliştirilmesinin gerektiği çalı̧malarda birim alanlardan yararlanmak araştırmacılara oldukça kolaylık sağlamaktadır. Dolayısıyla, varsayımsal komşuluk birimi
100 m’ye 100 m’lik (I ha) birim alanlara bölünmüştür (Şekil 7).

Ayrıca bu çalışmadaki diğer varsayımlar, başka bir deyişle mekânsal indeksin geliştirilmesi sırasında göz önünde bulundurulacak kabuller aşağıdaki gibi sıralanabilir (yine unutulmamalıdır ki farklı amaçlara sahip çalışmalarda bu varsayımlar da değişiklik gösterebilir):

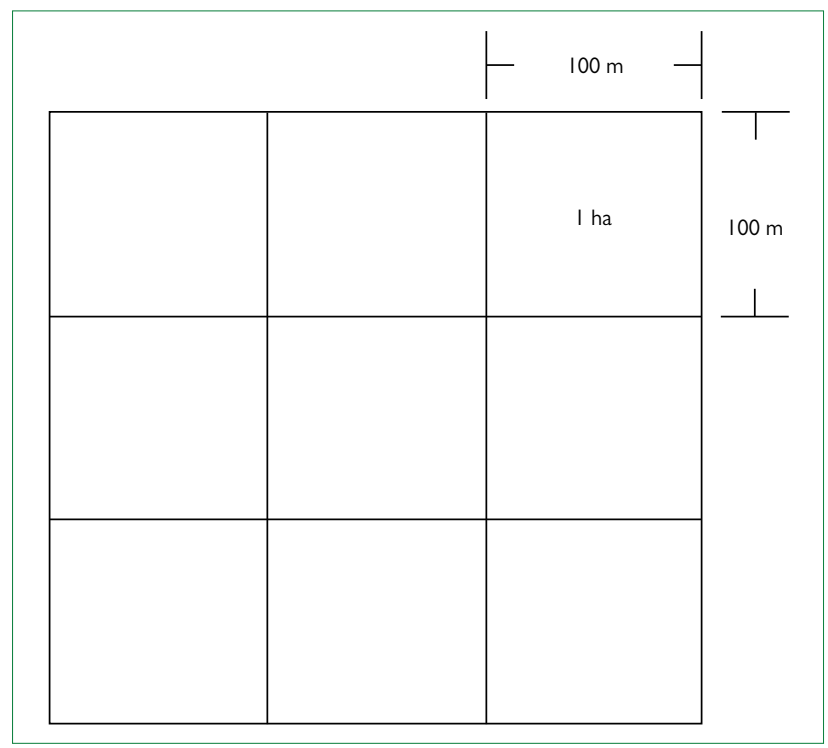

Şekil 7. Varsayımsal komşuluk birimi. 
- Kullanım çeşitliliğinin yüksek olması,

- Yoğunluk değerlerinin yüksek olması ve

- Komşuluk birimi tasarım ölçütlerinin sağlanmış olması bu örnekte istenen durumlardır.

Başka bir deyişle bu kabuller doğrultusunda örneğin; karma kullanımlı, derişik ve tasarım ölçütlerinin sağlandığı bir komşuluk biriminin sosyal sürdürülebilirliğe etkisinin inceleneceği bir çalışmada yapılı çevreyi ölçmek amacıyla, geliştirilen bu yöntem kullanılabilir. Dolayısıyla yukarıda tanımlanan kabullerin en fazla sağlandığı durumlar mekânsal indekste I değeriyle, hiç sağlanmadığı durumlarsa 0 değeriyle temsil edilecektir. Normalleştirme işlemleri de bu mantığa göre gerçekleştirilecektir. Bundan sonraki aşamalar madde madde anlatılacaktır:

I. Kullanım çeşitliliği yatay ve düşey düzlemlerdeki kullanım çeşitlilikleri olmak üzere iki farklı çerçevede ele alınacaktır. Yatay düzlemdeki kullanım çeşitliliğinin ölçülmesi amacıyla ilgili yazında gerçekleştirilen çalışmalarda kullanılan çeşitli hesaplama yöntemlerinden yararlanılabilir. Ancak bu örnekte Cervero ve Kockelman (1997) tarafından geliştirilen benzeşmezlik indeksinden yararlanılacaktır. Cervero ve Kockelman bu indeksi uygularken sadece konut, sanayi, ticaret, kamu vb. büyük ölçekli arazi kullanım türlerini ele almıştır. Ancak yapı ölçeğinde analizlerin gerektiği daha alt ölçekli çalışmalarda Cervero ve Kockelman'ın önerisi genişletilebilir. Dolayısıyla bu örnekte mekânsal indeks oluşturulurken ele alınan kullanım türleri şu şekilde sıralanmıştır: sadece konut $(k)$, sadece ticaret $(t)$, konut altı ticaret veya ticaretler $(k+t)$ ve kamu (ka). Bunların yanı sıra, geliştirilen bu varsayımsal örneğin mekânsal birimi görece küçük olduğundan ( $100 \mathrm{~m} \times 100 \mathrm{~m}$ birim alanlar), kullanım çeşitliliğinde daha anlamlı bir farklılaşma tespit edebilmek amacıyla sadece ticaret kullanımına sahip yapılardaki ticaret kullanımları perakende (p), ofis (o) ve imalat (i) alt başlıkları altında farklılaştırılmıştır. Bu farklılaştırmada daha fazla alt tür belirlenebilir ancak bu varsayımsal örnekte bu üçü ele alınacaktır.
Bu doğrultuda, benzeşmezlik indeksi Şekil 8'de gösterildiği gibi hesaplanmıştır. Birim alanlardaki sayıca fazla olan kullanım türleri baskın kullanımlar olarak varsayılmış ve bu kullanımlar birim alanlarda kısaltmalarıyla belirtilmiştir. Buna ek olarak, benzeşmezlik indeksinin hesaplanabilmesi için hesaplamanın gerçekleştirileceği birim alanın çevresindeki diğer birim alanların da kullanım türlerinin bilinmesi gerektiğinden, çevre birim alanlardaki baskın kullanım türleri de belirtilmiş ve bu alanların sınırları kesikli çizgilerle ifade edilmiştir.

Bunlara ek olarak, mekânsal indeks değerlerinin 0-I aralığındaki değerleri almasına karar verildiğinden (0-10, 0-100 vb. değerler de alabilir), ölçümden elde edilen sayısal değerler 0-I değer aralığında normalleştirilecektir. Ancak benzeşmezlik indeksi 0 -I arası değer aldığından, ayrıca normalleştirme işleminin gerçekleştirilmesine gerek yoktur.

2. Bu örnekte, düşey düzlemdeki kullanım çeşitliliğinin ölçülmesi için de Cervero ve Kockelman'ın (1997) geliştirdiği bir indeksten, düşey düzlemdeki çeşitlilik (vertical mixture) indeksinden yararlanılacaktır. Bu indeksin hesaplanabilmesi amacıyla birim alanlardaki birden fazla kullanım türüne sahip yapı sayısı (k) toplam yapı sayısına (t) bölünür. Burada da bir önceki maddede olduğu gibi sadece ticaret kullanımlı yapılardaki kullanım türleri perakende (p), ofis (o) ve imalat (i) alt başlıkları altında farklılaştırılmıştır. ${ }^{4}$ Elde edilen bu indeksin hesaplanması sonucunda da 0-I arası değerler elde edilmektedir (Şekil 9):

3. Kullanım çeşitliliğinin tespit edilebilmesi amacıyla yatay ve düşey düzlemlerdeki kullanım çeşitliliğini gösteren mekânsal indeksler basit ağırlıklı toplamla (simple additive weighting) bir araya getirilmiştir (Şekil 10). İndekslerin bir araya getirilmesi sonucunda 0 -I aralığının dışında değerler elde edildiğinden, bu değerlerin 0-I aralığına getirilebilmesi için normalleştirme işlemi gerçekleştirilmiştir. Kullanım çeşitliliğinin en yüksek olduğu birim alana ilişkin değer (I.04), I'e sabitlenmiş ve buna göre normalleştirme yapılmıştır.

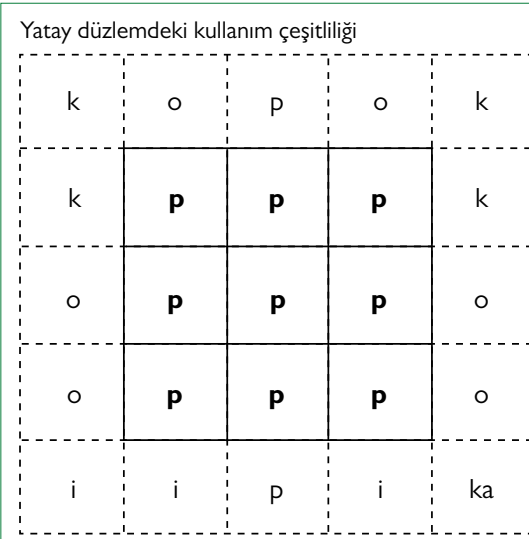

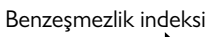

\begin{tabular}{|l|l|l|}
\hline $4 / 8$ & $2 / 8$ & $4 / 8$ \\
\hline $3 / 8$ & $0 / 8$ & $3 / 8$ \\
\hline $4 / 8$ & $2 / 8$ & $4 / 8$ \\
\hline
\end{tabular}

\begin{tabular}{|c|c|c|}
\hline 0.5 & 0.25 & 0.5 \\
\hline 0.37 & 0 & 0.37 \\
\hline 0.5 & 0.25 & 0.5 \\
\hline
\end{tabular}

Şekil 8. Yatay düzlemdeki kullanım çeşitliliğine ilişkin indeksin hesaplanma aşamaları.

4 Örneğin, bir yapının tüm katlarının bir giyim mağazası olduğu perakende kullanım çeşitli değildir. Ancak alt katı perakende üst katı ofis olan bir yapıda çeşitlilikten söz edilebilir. 


Düşey düzlemdeki kullanım çeşitlililğ
\begin{tabular}{|l|l|l|}
\hline $\begin{array}{l}k=6 \\
t=30\end{array}$ & $\begin{array}{l}k=4 \\
t=12\end{array}$ & $\begin{array}{l}k=8 \\
t=24\end{array}$ \\
\hline $\begin{array}{l}k=5 \\
t=35\end{array}$ & $\begin{array}{l}k=6 \\
t=48\end{array}$ & $\begin{array}{l}k=20 \\
t=10\end{array}$ \\
\hline $\begin{array}{l}k=7 \\
t=49\end{array}$ & $\begin{array}{l}k=2 \\
t=10\end{array}$ & $\begin{array}{l}k=12 \\
t=24\end{array}$ \\
\hline
\end{tabular}

Karma kullanımlı yapı sayısı/toplam yapı sayısı

\begin{tabular}{|l|l|l|}
\hline $6 / 36$ & $4 / 16$ & $8 / 32$ \\
\hline $5 / 40$ & $6 / 54$ & $20 / 30$ \\
\hline $7 / 56$ & $2 / 12$ & $12 / 36$ \\
\hline
\end{tabular}

\begin{tabular}{|l|l|l|l|}
\hline 0.17 & 0.25 & 0.25 \\
\cline { 2 - 4 } & 0.12 & 0.11 & 0.67 \\
\hline 0.12 & 0.17 & 0.33 \\
\hline
\end{tabular}

Şekil 9. Düşey düzlemdeki kullanım çeşitliliğine ilişkin indeksin hesaplanma aşamaları.

\begin{tabular}{|c|c|c|c|c|c|c|c|c|c|c|c|c|c|}
\hline \multicolumn{4}{|c|}{ Yatay düzlemdeki kullanım çeşitliliği } & \multicolumn{6}{|c|}{ Düşey düzlemdeki kullanım çeşitliliği } & & \multicolumn{3}{|c|}{ Kullanım çeşitliliği } \\
\hline 0.5 & 0.25 & 0.5 & \multirow{3}{*}{$\begin{array}{c}\text { Basit ağırıklı toplam } \\
+\end{array}$} & 0.17 & 0.25 & 0.25 & 0.67 & 0.5 & 0.75 & \multirow{2}{*}{ Normalleştirme } & 0.64 & 0.48 & 0.72 \\
\hline 0.37 & 0 & 0.37 & & 0.12 & 0.11 & 0.67 & 0.49 & 0.11 & 1.04 & & 0.47 & 0.10 & I \\
\hline 0.5 & 0.25 & 0.5 & & 0.12 & 0.17 & 0.33 & 0.62 & 0.42 & 0.83 & & 0.60 & 0.40 & 0.80 \\
\hline
\end{tabular}

Şekil I0. Kullanım çeşitliliğine ilişkin indeksin hesaplanma aşamaları.

\begin{tabular}{|c|c|c|c|c|c|c|}
\hline \multicolumn{3}{|c|}{ Ortalama yapılaşma yoğunluğu } & \multirow[b]{3}{*}{ KAKS } & \multirow[b]{2}{*}{2.4} & \multirow[b]{2}{*}{1.5} & \multirow[b]{2}{*}{2} \\
\hline $\begin{array}{l}k=6 \\
t=0.4\end{array}$ & $\begin{array}{l}k=5 \\
t=0.3\end{array}$ & $\begin{array}{l}k=5 \\
t=0.4\end{array}$ & & & & \\
\hline $\begin{array}{l}k=6 \\
t=0.5\end{array}$ & $\begin{array}{l}k=6 \\
t=0.7\end{array}$ & $\begin{array}{l}k=6 \\
t=0.6\end{array}$ & & 3 & 4.2 & 3.6 \\
\hline $\begin{array}{l}k=2 \\
t=0.5\end{array}$ & $\begin{array}{l}k=3 \\
t=0.3\end{array}$ & $\begin{array}{l}k=2 \\
t=0.4\end{array}$ & & I & 0.9 & 0.8 \\
\hline
\end{tabular}

\begin{tabular}{|c|c|c|c|}
\hline \multirow{2}{*}{ Normalleştirme } & 0.57 & 0.36 & 0.48 \\
\hline & 0.71 & I & 0.85 \\
\hline & 0.24 & 0.21 & 0.19 \\
\hline
\end{tabular}

Şekil I I. Ortalama yapılaşma yoğunluğuna ilişkin indeksin hesaplanma aşamaları.

4. Kullanım çeşitliliğine ilişkin mekânsal indeksin geliştirilmesinden sonra benzer işlemler yoğunluk için de uygulanmıştır. Bu örnekte yoğunluk, ortalama yapılaşma yoğunluğu ve ortalama nüfus yoğunluğu olmak üzere iki çerçevede incelenmiştir. Ortalama yapılaşma yoğunluğu KAKS yardımıyla hesaplanacaktır (ayrıca bkz. Mutlu, 2006). Bu amaçla öncelikle her bir birim alan için yapılaşmış taban alanları toplamı ve ortalama kat sayıları $(k)$ hesaplanır. Sonraki aşamada her bir birim alan içerisindeki yapılaşmış taban alanları toplamı, birim alanın alanına ( $10000 \mathrm{~m}^{2}$ veya I ha) bölünür. Böylelikle birim alan ölçeğinde taban alanı kat sayıları (TAKS - t) hesaplanmış olur (ayrıca bkz. Kısar-Koramaz ve Türkoğlu, 2010). Elde edilen TAKS değerleri ortalama kat sayılarıyla çarpılarak ortalama yapılaşma yoğunluğu elde edilir. Yoğunluğun en yüksek olduğu birim alanın sahip olduğu değer (4.2) l'e sabitlenir ve buna göre normalleştirme yapılır (Şekil II).

5. Ortalama nüfus yoğunluğu birim alanlar içerisindeki hane sayılarıyla tespit edilecektir. Dolayısıyla, Şekil I2'de birim alanlar içerisindeki hane sayıları belirtilmiştir. Hane sayıları orta- lama hane halkı büyüklüğüyle çarpılabilir ancak indeks değerinin elde edilmesinde bunun bir etkisinin olmayacağı için bu işlem gerçekleştirilmeyecektir. Bu doğrultuda, ortalama nüfus yoğunluğunun (başka bir deyişle hane sayılarının) en yüksek olduğu birim alan içerisindeki değer (40), I'e sabitlenmiş ve normalleştirme işlemi buna göre gerçekleştirilmiştir.

6. Yoğunluğun tek bir bileşen olarak ele alınabilmesi için yapılaşma ve nüfus yoğunluklarına ilişkin indeks değerleri basit ağırlıklı toplamla bir araya getirilmiştir. Ortalama yoğunluğun

\begin{tabular}{|c|c|c|c|c|c|c|}
\hline \multicolumn{3}{|c|}{ Ortalama nüfus yoğunluğu } & \multirow[b]{3}{*}{ Normalleştirme } & & & \\
\hline 30 & 10 & 40 & & 0.75 & 0.25 & I \\
\hline 20 & 5 & 10 & & 0.50 & 0.12 & 0.25 \\
\hline 15 & 10 & 5 & & 0.37 & 0.25 & 0.12 \\
\hline
\end{tabular}

Şekil I2. Ortalama nüfus yoğunluğuna ilişkin indeksin hesaplanma aşamaları. 
en yüksek olduğu birim alana ilişkin değer (1.48), I'e sabitlenmiş ve buna göre normalleştirme gerçekleştirilmiştir (Şekil I3).

7. Komşuluk birimi tasarım ölçütleri başlığında da tartışıldığı üzere, ilgili yazında farklı araştırmacılar tarafından geliştirilen çok sayıda ancak benzer komşuluk birimi tasarım ölçütü tanımlanmıştır. Bu örnekte, Farr (2008) tarafından tanımlanan ölçütlerden, ölçülebilen nitelikte olanların indeks değerleri hesaplanmıştır (Şekil 14). Bu doğrultuda ilk olarak, birim alanlarda bulunan 180 metreden geniş kenar uzunluğuna sahip yapı adası sayısı belirtilmiştir (bir yapı adasının iki birim alan içerisinde kalması durumunda yapı adasının orta noktasının bulunduğu birim alan için sayım gerçekleştirilir). Bu sayının en düşük olduğu birim alana ilişkin değer (2), I'e sabitlenmiş ve buna göre normalleştirme yapılmıştır. İkinci olarak, kentlilerin bir araya gelebileceği kentsel kullanım sayısı belirtilmiştir (bu örnekte sadece parklar ele alınmıştır; bu kullanımlar o alan için nirengi noktası yaratan yapılar da olabilir). Kentsel kullanım sayısının en yüksek olduğu değer
(3), I'e sabitlenmiş ve buna göre normalleştirme yapılmıştır. Sonrasında da alanlardaki çıkmaz sokak sayıları belirtilmiştir (Türkiye'de cul-de-sac kullanımları pek yaygın olmadığı için çıkmaz sokaklarla çok karşılaşılmayabilir). Çıkmaz sokak sayısının en düşük olduğu birim alana ilişkin değer (0), I'e sabitlenmiş ve buna göre normalleştirme gerçekleştirilmiştir (gerçek değerin 0 (sıfır) ve en istenen durum olduğu zamanlardaki hesaplama mantığı için bkz. Şekil I4'teki çıkmaz sokak sayısı örneği). Son olaraksa, en yakın ilkokula en fazla 400 metre uzaklıktaki birim alanlardan bu şartı sağlayanlara I, sağlamayanlaraysa 0 değeri verilmiştir. Farr, bir okulun varlığını komşuluk birimi için olmazsa olmaz bir kullanım olarak görmemiştir. Ancak komşuluk biriminin merkezinden çeperlerine yürüyerek en fazla 5 dakikada gidilebilmesi gerektiğini savunmuştur. Buna ilişkin mesafeyi de yaklaşık 400 metre olarak tanımlamıştır. Kullanım çeşitliliği ilk maddelerde hesaplandığı için çifte hesaplamaya (double-counting) sebebiyet vermemek amacıyla hesaplamaya dâhil edilmemiştir.

\begin{tabular}{|c|c|c|c|c|c|c|c|c|c|c|c|c|c|}
\hline \multicolumn{3}{|c|}{ Ortalama yapılaşma yoğunluğu } & & \multicolumn{3}{|c|}{ Ortalama nüfus yoğunluğu } & & & & & \multicolumn{3}{|c|}{ Yoğunluk } \\
\hline 0.57 & 0.36 & 0.48 & \multirow{3}{*}{$\begin{array}{l}\text { Basit ağırıklı toplam } \\
+\end{array}$} & 0.75 & 0.25 & I & 1.32 & 0.61 & 1.48 & \multirow{3}{*}{ Normalleştirme } & 0.89 & 0.41 & I \\
\hline $0.7 I$ & I & 0.85 & & 0.50 & 0.12 & 0.25 & 1.21 & 1.12 & 1.10 & & 0.82 & 0.75 & 0.74 \\
\hline 0.24 & 0.21 & 0.19 & & 0.37 & 0.25 & 0.12 & $0.6 I$ & 0.46 & 0.31 & & 0.41 & 0.31 & 0.21 \\
\hline
\end{tabular}

Şekil 13. Yoğunluğa (yapılaşma ve nüfus derişikliğine) ilişkin indeksin hesaplanma aşamaları.

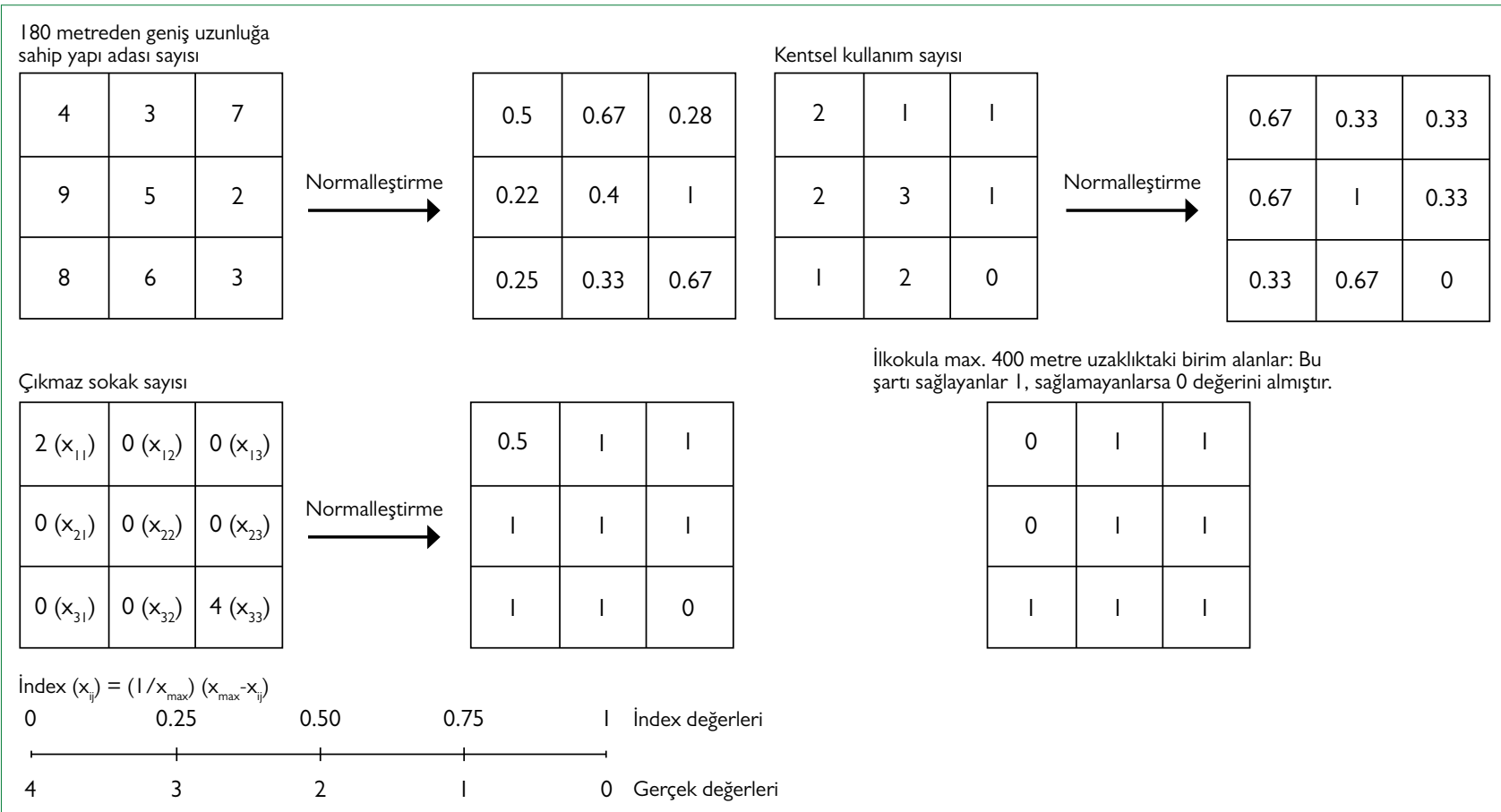

Şekil 14. Komşuluk birimi tasarım ölçütlerine ilişkin indekslerin hesaplanma aşamaları.

(çıkmaz sokak sayısı örneğindeki formülde: $x_{i j}$ : birim alanlardaki değerleri, $x_{\max }$ : birim alanlardaki en büyük değeri ifade eder). 
180 metreden geniş kenar uzunluğuna sahip yapı adası ve çıkmaz sokak sayıları için gerçekleştirilen indeks hesaplarında, önceki hesaplamaların aksine en küçük değer l'e sabitlenmiştir. Çünkü geniş kenar uzunluğuna sahip yapı adalarının ve çıkmaz sokakların oluşumu komşuluk birimi tasarımında istenmeyen durumlardır. Buna ek olarak, gerçek değerin 0 ve en çok istenen olduğu durumlarda ilgili mekânsal indeks, Şekil I4'deki çıkmaz sokak sayısı örneğindeki formüldeki mantık izlenerek hesaplanmıştır.

8. Ölçülebilir nitelikteki tasarım ölçütlerinin indeks değerleri bir araya getirilmiştir. Komşuluk birimi tasarımı ölçütlerini en fazla sağlayan birim alanın değeri (3.4), I'e sabitlenmiştir (Şekil I5).

9. Yöntemin uygulanışına geçilmeden önce sıralanan varsayımlara dayanarak kullanım çeşitliliği, yoğunluk ve komşuluk birimi tasarımı ölçütlerine ilişkin indeks değerleri bir araya getirilmiştir. Dolayısıyla arazi kullanımı, yoğunluk ve tasarıma ilişkin planlama kararlarının bir sonucu olarak yapılı çevreyi biçimlendiren bu üç bileşenin bütüncül bir çerçevede birlikte ele alındığı bir mekânsal indeks geliştirilmiştir. Bu doğrultuda, normalleştirme işleminde en büyük değer (2.72), I'e sabitlenmiştir (Şekil 16).

\section{Tartışma ve Sonuç}

Bu çalışma kapsamında kullanım çeşitliliğinin ve yoğunluk değerlerinin yüksek olmasıyla, giriş bölümündeki Tablo 2'de tanımlanan komşuluk birimi tasarımını biçimlendiren kararların; Farr (2008)'ın geliştirdiği ölçütler doğrultusunda alınmış olması, yöntemin uygulanışına geçmeden önce göz önünde bulundurulacak kabuller olarak tanımlanmıştır. Dolayısıyla, bu kabullerin en fazla sağlandığı durumlar geliştirilen mekânsal indekste I değeriyle, göreceli olarak az sağlandığı durumlarsa sıfıra yaklaşan değerlerle temsil edilmiştir. Özetlemek gerekirse, açıklanan varsayımsal örnekte sonuç olarak (bkz. Şekil I6) I değeriyle betimlenen alan çeşitliliğin, yoğunluğun ve tasarım ölçütlerinin eşit oranlarda bir araya getirilmesiyle değerlendirildiği ve bu üç bileşene ilişkin giriş bölümünde tanımlanan ka- ilkokula max. 400 metre uzaklıktaki birim alanlar: Bu şartı sağlayanlar I, sağlamayanlarsa 0 değerini

\begin{tabular}{|c|c|c|}
\hline \multicolumn{3}{c|}{ almıştır. } \\
\hline 0 & 1 & 1 \\
\hline 0 & 1 & 1 \\
\hline 1 & 1 & 1 \\
\hline
\end{tabular}

\begin{tabular}{|c|c|c|c|}
\hline & \multicolumn{3}{|c|}{ Çıkmaz sokak sayısı } \\
\hline & 0.5 & I & I \\
\hline \multirow{2}{*}{+} & 1 & I & l \\
\hline & 1 & I & 0 \\
\hline
\end{tabular}

180 metreden geniş uzunluğa

\begin{tabular}{|c|c|c|}
\multicolumn{3}{|c|}{ sahip yapı adası sayısı } \\
\hline 0.5 & 0.67 & 0.28 \\
\hline 0.22 & 0.4 & 1 \\
\hline 0.25 & 0.33 & 0.67 \\
\hline
\end{tabular}

Kentsel kullanım sayıs

\begin{tabular}{|c|c|c|}
\hline 0.67 & 0.33 & 0.33 \\
\hline 0.67 & 1 & 0.33 \\
\hline 0.33 & 0.67 & 0 \\
\hline
\end{tabular}

Basit ağırlıklı toplam

Basit ağırıklı toplam

Basit ağılıklı toplam

Komşuluk birimi tasarımı ölçüleri

$\rightarrow$\begin{tabular}{|c|c|c|}
\hline 1.67 & 3 & 2.61 \\
\hline 1.89 & 3.4 & 3.33 \\
\hline 2.58 & 3 & 1.67 \\
\hline
\end{tabular}

\begin{tabular}{|c|c|c|}
\hline 0.49 & 0.88 & 0.77 \\
\hline 0.55 & 1 & 0.98 \\
\hline 0.76 & 0.88 & 0.49 \\
\hline
\end{tabular}

Şekil I5. Komşuluk birimi tasarım ölçütlerine ilişkin indeksin hesaplanma aşamaları.

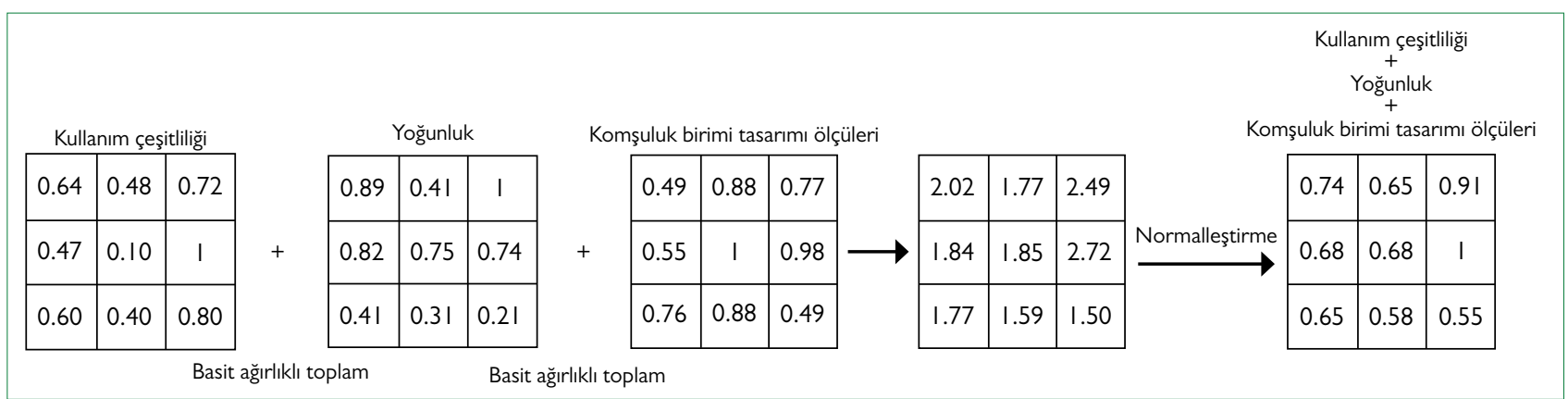

Şekil I6. Arazi kullanımı, yoğunluk ve komşuluk birimi tasarımına ilişkin planlama kararlarının sonuçlarının ölçümü için geliştirilen mekânsal indeks. 
bullerin bir arada göreceli olarak en fazla sağlandığı alanı ifade etmektedir. Önceki aşamalarda geliştirilen ve Şekil I6'da girdi olarak kullanılan kullanım çeşitliliği, yoğunluk ve komşuluk birimi tasarım ölçütlerine ilişkin ayrı ayrı geliştirilen mekânsal indeks değerleri, fiziksel mekânın özelliklerini nitelendirdiklerinden, farklı çalışmalarda kendi başlarına da kullanılabilirler. Örneğin kullanım çeşitliliğine ilişkin geliştirilen mekânsal indeks değerlendirilecek olursa, I değerine sahip alan yatay ve düşey düzlemlerde arazi kullanım çeşitliliğinin en fazla olduğu, 0.10 değerine sahip alansa en az olduğu birim alanı ifade etmektedir.

Ayrıca şunu belirtmek gerekir ki arazi kullanımına, yoğunluğa ve komşuluk birimi tasarımına ilişkin planlama kararlarıyla ilişkili sonuçların basit ağırıklı toplam yoluyla bir araya getirilmesiyle elde edilen mekânsal indekste (bkz. Şekil 16) I değeriyle tanımlanan alan, değerlerin eşit ağırlıklarla bir araya getirilmesi sonucunda en yüksek değerin elde edildiği alanı göstermektedir. Eğer ki başta tanımlanan kabullerde bu sonuçlardan herhangi birine öncelik verilseydi (ör. çeşitliliğin sağlanması daha önemliyse), arazi kullanım çeşitliliği için daha yüksek bir ağırlık değeri verilerek (ör. çeşitlilik=0.4, yoğunluk=0.3, tasarım=0.3), indeks değerleri bu ağırlıklarla çarpılacak ve bu çarpım sonucu elde edilen değerler basit ağırıklı toplam ile bir araya getirilerek hesaplama süreci devam ettirilecekti.

Arazi kullanımı, yoğunluk ve tasarıma yönelik planlama kararları, yaşadığımız yapılı çevreyi biçimlendiren en önemli unsurlardır. Bu kararlar, kentin genel siluetini etkilediği gibi kentte yaşayanların günlük yaşantıları üzerinde de büyük bir etkiye sahiptir. Örneğin bir komşuluk biriminde konut dışı kullanımların çeşitlilik göstermesi, yaşayanların sürdürülebilir ulaşım türlerini (yürüyüş, bisiklet ve toplu taşıma) kullanarak günlük ihtiyaçlarını yakın mesafelerde karşılayabilmesi bakımından önemlidir. Yaşayanlardaki bu tür bir davranış, karbon salınımının azaltılmasına katkıda bulunarak çevresel sürdürülebilirliğin devam ettirilebilmesine olanak sağlar. Bir diğer taraftan, yoğunluk kararları ele alındı̆̆ında yaşanılan çevrenin yoğun bir yerleşimden oluşması, yaşayanların yaşadıkları yere olan aidiyet duygusunu olumlu veya olumsuz etkileyebilmektedir. Bu da sosyal sürdürülebilirliğe doğrudan etkisi olan bir durumdur. Benzer biçimde, komşuluk biriminde belirli tasarım ölçütlerinin sağlanması yaşayanların hayatını kolaylaştıran en önemli etkenlerden biridir. Çeşitli araştırmacılar tarafından geliştirilen tasarım ölçütleri dikkate alınarak geliştirilen komşuluk birimlerinde yaşayanlar, yürüme uzaklığı içerisinde önemli kentsel kullanım ve hizmetlerin yanı sıra günlük ihtiyaçlarını karşılayabilecekleri alışveriş olanaklarına sahiptirler. Bu da komşuluk birimi içerisinde yaşayan topluluğun sosyal, çevresel ve ekonomik sürdürülebilirliğinin sağlanması bakımından önemlidir. $\mathrm{Bu}$ çerçevede gerçekleştirilmiş çok sayıda araştırma ve derleme bulunmaktadır (yapılı çevre-sağlık, yapılı çevre-sosyal sürdürülebilirlik, yapılı çevre-çevresel sürdürülebilirlik, yapılı çevre-ekonomik sürdürülebilirlik üzerine) (ör. bkz. Cervero ve Kockelman, 1997; Talen, 1999; Leyden, 2003; Bramley vd., 2009; Bramley ve Power, 2009; Dempsey vd., 2012; Witten vd., 20I2). Ancak bu araştırmaların çok azı yapılı çevreyi kullanım çeşitliliği, yoğunluk ve tasarım ölçütleri çerçevesinde, bu üçünün bir arada yer aldığı bütüncül bir yaklaşım benimseyerek ele almıştır.

Bu doğrultuda, giriş bölümünde oluşturulan araştırma sorusunun cevabı olarak bu çalışmayla arazi kullanımı, yoğunluk ve komşuluk birimi tasarımı kararları çerçevesinde yapılı çevreyi biçimlendiren planlama kararlarına ilişkin sonuçların (kullanım çeşitliliği, yoğunluk durumu ve tasarım ölçütlerinin sağlanıp-sağlanmadığı çerçevesinde), bütüncül bir çerçevede nasıl ölçülebileceğine ilişkin bir yöntem önerisi geliştirilmiştir. Bu çerçevede geliştirilen yöntemin temelleri birim alanlara (grid) ve bileşenlere ilişkin mekânsal indekslere dayanmaktadır. Verilen örnekte ilk olarak her bir planlama kararı sonucuna ilişkin mekânsal indeks oluşturulmuş, sonrasında da oluşturulan bu indeksler bir araya getirilerek yapılı çevreyi bir bütün olarak niceliksel çerçevede tanımlayan genel bir mekânsal indekse ulaşılmıştır. Dolayısıyla geliştirilen bu yöntem, planlama kararlarının bir bütün olarak doğrudan ve sayısal çerçevede mekân üzerinde okunması bakımından kullanışlı bir yöntemdir. Bunlara ek olarak, önerilen bu yöntem esnek bir yapıya sahip olduğundan herhangi bir komşuluk birimi için farklı değişkenler kullanılarak uygulanabilir. Böylelikle planlama kararlarının yapılı çevreyi biçimlendiren somut sonuçları, rakamlarla ve doğrudan mekân üzerinde tespit edilebilir.

\section{Teşekkür}

Bu çalışma, Gazi Üniversitesi Bilimsel Araştırma Projeleri (BAP) Birimi tarafından, Doktora Tezi Projesi kapsamında desteklenmiştir (Proje No: 48/20I8-0I). 


\section{KAYNAKLAR}

Alexander, E. R. (1993). Density Measures: A Review and Analysis. Journal of Architectural and Planning Research, 10(3), 181-203. http://www.jstor. org/stable/43031090.

American Planlama Derneği (2017). Characteristics and guidelines of great neighborhoods. https://www.planning.org/greatplaces/neighborhoods/ characteristics.htm

Atkinson, A. B. (1970). On the measurement of inequality. Journal of economic theory, 2(3), 244-263.

Bourne, L. S. (1976). Urban Structure and Land Use Decisions. Annals of the Association of American Geographers, 66(4), 531-535. http://doi. org/10.1111/j.1467-8306.1976.tb01108.x.

Boyko, C. T., \& Cooper, R. (2011). Clarifying and re-conceptualising density. Progress in Planning, 76(1), 1-61. http://doi.org/10.1016/j.progress.2011.07.001.

Bölen, F., Türkoğlu, H. D., \& Yirmibeșoğlu, F. (2009). İstanbul'da yapıllaşma yoğunluğu - yaşanabilir alan ilişkisi. Itüdergisi/a Mimarlık, Planlama, Tasarım, 8(1), 127-137.

Bramley, G., Dempsey, N., Power, S., Brown, C., \& Watkins, D. (2009). Social sustainability and urban form: evidence from five British cities. Environment and Planning A, 41(9), 2125-2142. http://doi.org/10.1068/ a4184.

Bramley, G., \& Power, S. (2009). Urban form and social sustainability: The role of density and housing type. Environment and Planning B: Planning and Design, 36(1), 30-48. http://doi.org/10.1068/b33129.

Brown, B. B., Yamada, I., Smith, K. R., Zick, C. D., Kowaleski-Jones, L., \& Fan, J. X. (2009). Mixed land use and walkability: Variations in land use measures and relationships with BMI, overweight, and obesity. Health and Place, 15(4), 1130-1141. http://doi.org/10.1016/j.healthplace.2009.06.008.

Burton, E. (2000). The Compact City: Just or Just Compact? A Preliminary Analysis. Urban Studies, 37(11), 1969-2006. http://doi. org/10.1080/00420980050162184.

Calgary Bölgesel Birliği. (2011). Greenfield Tool Box for Implementation of the Calgary Metropolitan Plan's Compact Settlement Land Use and Development Policies.

Cervero, R., \& Duncan, M. (2003). Reviewing the evidence. Walking, bicycling, and urban landscapes: evidence from the San Francisco Bay area. American Journal of Public Health, 93(9), 1478-1483. http://doi. org/10.2105/AJPH.93.9.1478.

Cervero, R., \& Kockelman, K. (1997). Travel Demand and The 3ds : Density, Design And Diversity. Transportation Research Part D: Transport and Environment, 2(3), 199-219. http://doi.org/10.1016/S13619209(97)00009-6.

Cheng, V. (2010). Understanding density and high density. In E. Ng (Ed.), Designing high-density cities for social and environmental sustainability (pp. 3-17). London: Earthscan.

Churchman, A. (1999). Disentangling the Concept of Density. CPL Bibliog raphy, 13(4), 389-411. http://doi.org/10.1177/08854129922092478.

Congress for The New Urbanism. (2001). Charter of The New Urbanism.

Dave, S. (2009). Neighbourhood density and social sustainability in cities of developing countries. Sustainable Development. https://doi. org $/ 10.1002 /$ sd.433.

Day, K. (2003). New Urbanism and the Challenges of Designing for Diversity. Journal of Planning Education and Research, 23(1), 83-95. https://doi. org $/ 10.1177 / 0739456$ X03255424

Dempsey, N., Brown, C., \& Bramley, G. (2012). The key to sustainable urban development in UK cities? The influence of density on social sustainability. Progress in Planning, 77(3), 89-141. http://doi.org/10.1016/j. progress.2012.01.001.

Department of the Environment, Transport and the Regions (DETR) (1998). Planning research programme: The use of density in urban planning. London: TSO.
Dovey, K., \& Pafka, E. (2014). The urban density assemblage: Modelling multiple measures. URBAN DESIGN International, 19(1), 66-76. http:// doi.org/10.1057/udi.2013.13.

Duany, A., \& Plater-Zyberk, E. (1994). The neighborhood, the district and the corridor. The New Urbanism: Toward an Architecture of Community, McGraw-Hill, New York, xvii-xx.

Farr, D. (2008). Sustainable urbanism: Urban design with nature. Hoboken, New Jersey: John Wiley \& Sons, Inc.

Forsyth, A. (2003). Measuring Density: Working Definitions for Residential Density and Building Intensity. Design Center for American Urban Landscape, 8(8), 2-8.

Frank, L. D., \& Pivo, G. (1994). Impacts of mixed use and density on utilization of three modes of travel: Single occupant vehicle, transit, and walking. Transportation Research Record: Journal of the Transportation Research Board, 1466, 44-52. http://doi.org/10.1073/pnas.1100480108.

Grant, J. (2002). Mixed Use in Theory and Practice: Canadian Experience with Implementing a Planning Principle. Journal of the American Planning Association, 68(February 2015), 71-84. https://doi. org/10.1080/01944360208977192.

HATC. (2010). Room to swing a cat? The amount and use of space in new dwellings in London \& the South East Ilkley, West Yorkshire: HATC Limited.

Holden, E., \& Norland, I. (2005). Three challenges for the compact city as a sustainable urban form: Household consumption of energy and transport in eight residential areas in the greater Oslo Region. Urban Studies, 42(12), 2145-2166. http://doi.org/10.1080/00420980500332064.

Hoppenbrouwer, E., \& Louw, E. (2005). Mixed-use development: Theory and practice in Amsterdam's Eastern Docklands. European Planning Studies, 13(7), 967-983. https://doi.org/10.1080/09654310500242048.

Kisar-Koramaz, E., \& Türkoğlu, H. (2010). Neighboring As asn Indicator of Social Integration in Residential Areas of Istanbul. In 14th IPHS Conference: Urban Transformation: Controversies, Contrasts and Challanges (pp. 1-10). İstanbul.

Kockelman, K. (1997). Travel Behavior as Function of Accessibility, Land Use Mixing, and Land Use Balance: Evidence from San Francisco Bay Area. Transportation Research Record, 1607(1), 116-125. http://doi. org/10.3141/1607-16

Lau, S. S. Y., Giridharan, R., \& Ganesan, S. (2005). Multiple and intensive land use: Case studies in Hong Kong. Habitat International, 29(3), 527546. https://doi.org/10.1016/j.habitatint.2004.04.007.

Leyden, K. M. (2003). Social Capital and the Built Environment: The Importance of Walkable Neighborhoods. American Journal of Public Health, 93(9), 1546-1551. http://doi.org/10.2105/AJPH.93.9.1546.

Manaugh, K., \& Kreider, T. (2013). What is mixed use? Presenting an interaction method for measuring land use mix. Journal of Transport and Land Use, 6(1), 63-72. http://doi.org/10.5198/jtlu.v6i1.291.

Massey, D. S., \& Denton, N. a. (1988). The Dimensions of Residential Segregation. Social Forces, 67(2), 281-315. http://doi.org/10.1093/ sf/67.2.281.

Mutlu, H. (2006). İstanbul Metropolitan Alanında kentsel Arazi Değerlerinin Mekansal Dağılımının Analizi. Yüksek Lisans Tezi, İTÜ.

Newman, P., \& Hogan, T. (1981). A Review of urban density models: Toward a resolution of the conflict between populace and planner. Human Ecology, 9(3), 269-303. http://doi.org/10.1007/BF00890739.

Park, Y., \& Rogers, G. O. (2015). Neighborhood Planning Theory, Guidelines, and Research. CPL Bibliography, 30(1), 18-36. http://doi. org/10.1177/0885412214549422.

Perry, C. (2013). The Neighborhood Unit. Michael Larice \& Elizabeth Macdonald (ed.), The urban design reader (ss. 78-89). New York: Routledge.

Pont, M. B., \& Haupt, P. (2010). Spacematrix: space, density and urban form. Retrieved from https://ezp.lib.unimelb.edu.au/login?url=https:// search.ebscohost.com/login.aspx?direct $=$ true $\& \mathrm{db}=$ cat00006 $\& \mathrm{AN}=\mathrm{m}$ elb.b4036900\&scope $=$ site.

Porta, S., \& Renne, J. L. (2005). Linking urban design to sustainability: formal indicators of social urban sustainability field research in Perth, West- 
ern Australia. Urban Design International, 10(1), 51-64. http://doi. org/10.1057/palgrave.udi.9000136.

Rohe, W. M. (2009). From Local to Global: One Hundred Years of Neighborhood Planning. Journal of the American Planning Association, 75(2), 209-230. http://doi.org/10.1080/01944360902751077.

Rowley, A. (1996). Mixed-use Development: Ambiguous concept, simplistic analysis and wishful thinking? Planning Practice and Research, 11(1), 85-98. https://doi.org/10.1080/02697459650036477.

Silver, C. (1985). Neighborhood Planning in Historical Perspective. Journal of the American Planning Association, 51(February 2015), 161-174. http://doi.org/10.1080/01944368508976207.

Song, Y., Merlin, L., \& Rodriguez, D. (2013). Comparing measures of urban land use mix. Computers, Environment and Urban Systems, 42, 1-13. http://doi.org/10.1016/j.compenvurbsys.2013.08.001.

Song, Y., \& Rodríguez, Da. (2005). Carolina Transportation Program White Paper Series The Measurement of the Level of Mixed Land Uses : A Synthetic Approach.

Srinivasan,S.(2002). QuantifyingSpatialCharacteristics of Cities. UrbanStudies, 39(11), 2005-2028. http://doi.org/10.1080/004209802200001133

Talen, E. (1999). Sense of Community and Neighbourhood Form : An Assessment of the Social Doctrine of New Urbanism, 36(8), 1361-1379.

Taylor, Z., \& Nostrand, J. (2008). Shaping the Toronto Region, Past, Present, and Future.

Terzi, F., \& Bölen, F. (2010). İstanbul'da şehirsel saçaklanmanın ölçülmesi. Itüdergisi/a Mimarlık, Planlama, Tasarım, 9(2), 166-178.

Türkoğlu, H. D. (1997). Residents' satisfaction of housing environments: the case of Istanbul, Turkey. Landscape and Urban Planning, 39, 55-67.

Witten, K., Blakely, T., Bagheri, N., Badland, H., Ivory, V., Pearce, J., ... Schofield, G. (2012). Neighborhood Built Environment and Transport and Leisure Physical Activity: Findings Using Objective Exposure and Outcome Measures in New Zealand. Environmental Health Perspectives, 120(7), 971-977. http://doi.org/10.1289/ehp.1104584.

Yang, Y. (2008). A Tale of Two Cities: Physical Form and Neighborhood Satisfaction in Metropolitan Portland and Charlotte. Journal of the American Planning Association, 74(3), 307-323. http://doi. org $/ 10.1080 / 01944360802215546$.

Yigitcanlar, T., Dur, F., \& Dizdaroglu, D. (2014). Towards prosperous sustainable cities: A multiscalar urban sustainability assessment approach. Habitat International, 45, 36-46. http://doi.org/10.1016/j.habitatint.2014.06.033. 